\title{
THE POLITICS OF POST-SUBURBAN DENSIFICATION IN CANADA AND FRANCE
}

\author{
Eric Charmes and Roger Keil
}

Published in International Journal of Urban and Regional Research, Volume39, Issue3, May 2015, pages 581-602, "Debates \& Developments"

\begin{abstract}
This debate specifically focuses on densification as a particular dimension of (post-) suburbanization. In the introduction, we discuss densification, along with 'compactness' and 'intensification', conceptual terms that have become buzzwords within urban planning. Objectives associated with these tend to be presented in the literature within a normative framework, structured by a critique of the negative effects attributed to sprawl. The perspective here is different. It is not normative but critical, and articulated around the analysis of political and social issues, related to the transformation of wider metropolitan space. Three main themes are developed: (1) the politics of densification (the environmental arguments favouring densification are highly plastic, and are thus often used to defend projects or initiatives which are actually determined by other agendas); (2) why morphology matters (a similar number of houses or square metres can be established in many different ways, and those different ways have political and social meaning); (3) the diversity of suburban densification regimes (it is not only the landscapes of the suburbs that are diverse, but also the local bodies governing them-between the small residential municipalities of the Paris periurbs and the large inner suburbs of Toronto lies a broad spectrum).
\end{abstract}

\section{Introduction $^{1}$}

While newly developed areas of North America and Western Europe continue to be filled with detached single-family dwellings (see Figure 1), many older suburbs are changing (Harris, 2010; Hamel and Keil, 2015). This process has been described as post-suburbanization (Phelps and Wu, 2011a). It does not affect all suburbs, and resistance to change is strong (Filion, 2015, this issue), but the changes are significant in many places. It is important to state that we are not talking here about a distinct typology-suburbs versus post-suburbs-but rather a historical change in direction: a process of dedensification (classical suburbanization) is partly converted, inverted or subverted into a process that involves densification, complexification and diversification of the suburbanization process (see Figure 2). Los Angeles, for example, long viewed as the ultimate suburban city, is really one of the densest metropolitan areas in the United States, an 'inverted city' where suburbanization has begun to fold in on itself as areas traditionally considered sprawling, mono-cultural and mono-functional have

\footnotetext{
${ }^{1}$ We are extremely grateful to Imelda Nurwisah for translating the original draft of this introduction from French into English. The Canadian part of the research presented here was supported by the Social Sciences and Humanities Research Council of Canada through funding from the Major Collaborative Research Initiative 'Global Suburbanisms: Governance, Land and Infrastructure in the 21st Century' (2010-17). The French part of the research was supported by the French National Research Agency (ANR) within the framework of the 'Sustainable City' research programme.
} 
increasingly become denser, more multicultural and mixed in use. In the European case, postsuburbanization involves a slight shift in focus from the discourse on the traditional (dense, centralized, politically integrated) European city—as argued masterfully by Patrick Le Galès (2002) - to a model that acknowledges the dissolution as posited in the literature on the 'in-between city' or zwischenstadt (Sieverts, 2003). In the Canadian case, we have witnessed the turn away from the classical North American model, with its clear separation of classical nineteenth-century industrial inner city and twentieth-century suburbanization, towards 'in-between' or 'post-suburban' forms of peripheral urbanization: in this process, the post-second world war 'inner suburbs' with their particular assemblage of issues-decaying high-rise housing stock, concentrations of poverty, mobility imbalances, often racialized social segregation, a dramatic lack of services, etc.- - have become a focus of attention among researchers (Hulchanski, 2010; Young et al., 2011; Keil and Young, 2013; Poppe and Young, 2015, this issue).

Figure 1: An artist's view of an archetypical outer-suburban development in France (Jean-Pierre Attal, intra-muros 12, 74×100 cm, 2008, www.jeanpierreattal.com)

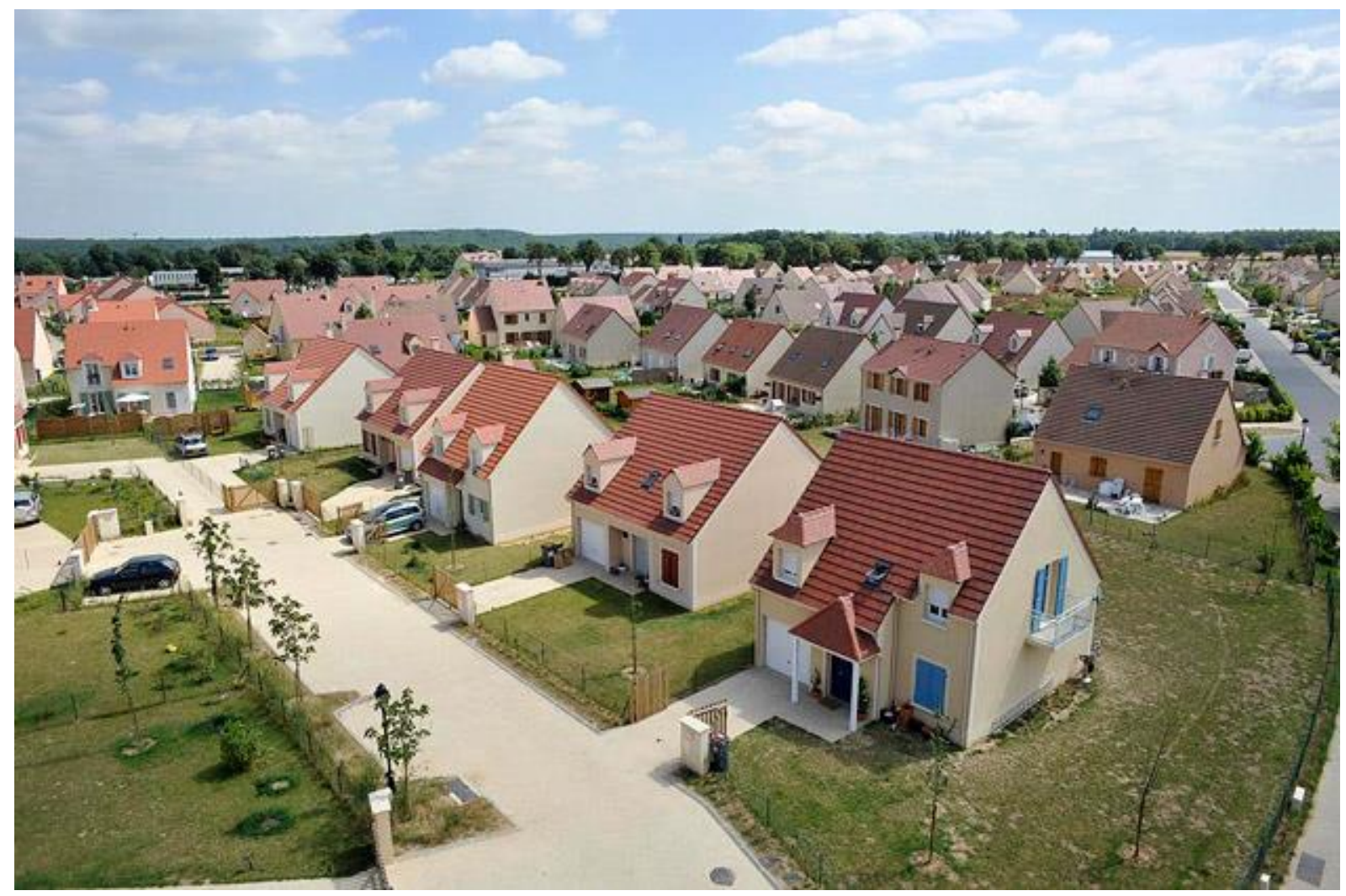

As the growing literature on post-suburbs shows, such processes are by no means ignored. We can consult the most comprehensive and influential recent contribution to the debate on postsuburbanization in the introduction to a recent collection of studies on the subject by Phelps and Wu (2011a). In this view, post-suburbanization refers primarily to an era involving a double re-definition of classical suburbia: a 'maturation' of the suburbs and a host of new influences changing the nature of those areas. Some interventions, like the extensive literature on Los Angeles since the 1980s, have gone so far as to claim an epochal shift in urbanization patterns. More broadly, however, post-suburbia entails the notion of a reversal of the linearity of historical processes, as traditional geographical 
typologies of ordered concentric segmentation have given way to a more splintered or fragmented urbanism (as encountered under broader processes of neoliberalization). Post-suburbanization does not refer to a complete and featureless dissolution but to a reconsolidation of the urban fabric, even a balancing, and a rejection of classical functional or conceptual dichotomies such as live-work. This is particularly the case in the technoburbs that have been associated with the process. Postsuburbanization also entails a profound re-scaling of the relations and modes of governance that have traditionally regulated the relationships between centre and periphery in the suburban model (Phelps and Wood, 2011; Phelps and Wu, 2011b;Hamel and Keil, 2015).

In this contribution to Debates \& Developments in IJURR, we specifically focus on densification as a particular dimension of (post-)suburbanization. This introduction and the four essays that follow make no larger claims about suburbanization in France and Canada or even their comparative trajectories. Yet we do think that these essays have significance in engaging critically with the strategic and normative preference for density and compactness in a sustainability paradigm that often remains unchallenged on both sides of the Atlantic. In this context the Canadian and French examples, and their comparison through the work presented here, is valuable. Low-density morphological patterns have not only been at the heart of the original programme of suburban utopia with its setting of pastoral life (Fishman, 1987), but they are also key to understanding the recent transformation of suburbs. Yet in both national contexts under review here, Canada and France, higher-density peripheral development has also been part of the development regime since as far back as the 1960s. More recently (and most relevant to the debate presented here), densification, along with 'compactness' and 'intensification', have become buzzwords in urban planning.

Figure 2: In-between city Toronto: York University campus at the northwestern edge of Toronto looking south (photo by Roger Keil)

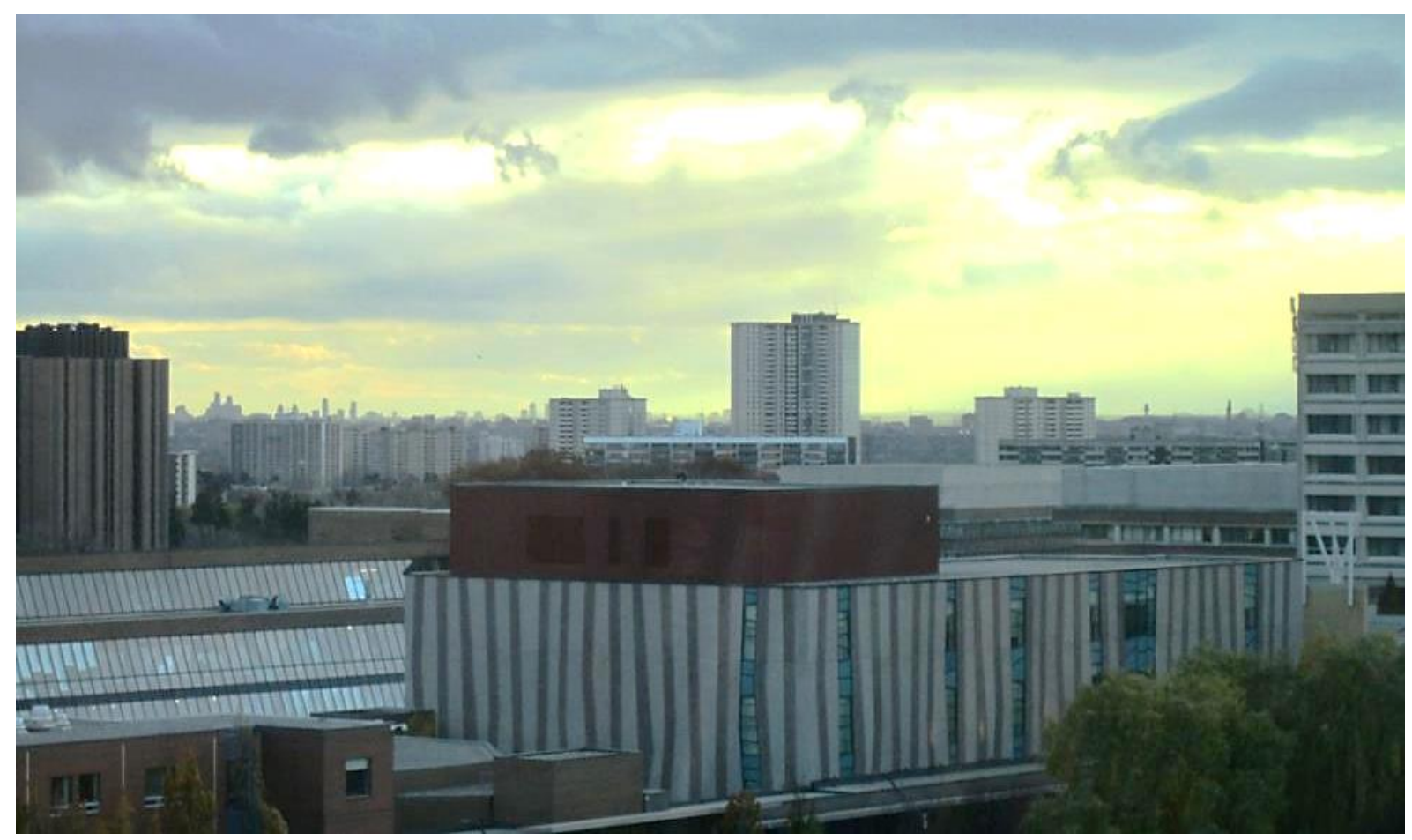


Objectives associated with densification tend to be presented in the literature within a normative framework, structured by a critique of the negative effects attributed to sprawl. There is a wealth of propositions under the banners of New Urbanism or Smart Growth in North America and Sustainable Cities in Europe, around the 'battle against urban sprawl' and the need to increase the density of cities to make them more resilient and sustainable. Our perspective here is different. It is not normative but critical, and articulated around the analysis of political and social issues, related to the transformation of wider metropolitan space.

The aim of this debate is to document with empirical surveys the issues at stake with densification policies. These transformations serve certain interests yet neglect many others. They often lead to displacement of less well-off populations. More broadly, their geography is uneven, predominantly targeting the low-income and working-class suburbs. The success of the themes of densification and of the battle against urban sprawl should also be related to the fact that those themes converged with the interests of urban planners (under the buzzwords of growth control), politicians in core urban areas (who welcome new residents and activities) and developers (who can exploit the rent gap, new opportunities, etc.). Besides, the need for dense cities is a convenient argument in overcoming the strong local resistance to urban development (see below).

Such critical perspective has of course already been developed in the literature. Among others, John Logan and Harvey Molotch (2007 [1987]: xx) noted (in the second edition of their book Urban Fortunes) that densification not only serves environmental interests but also helps defend the 'same old growth machine'. Emergence of consensual discourse on sustainable development is often accompanied by de-politicization of the issues at stake (Béal et al., 2011). The gravitas gained by sustainable development ideology contributes to silencing debates on political and social issues. Sustainability itself becomes the stand-in for better (sub)urbanization and is not usually exposed to critical scrutiny (Keil and Whitehead, 2012). For example, the website of Richard Rogers' planning and architecture practice (one of the leading proponents of compactness) proclaims that 'Compact polycentric cities are the only sustainable form of development' (Rogers Stirk Harbour + Partners, n.d.). Since the survival of humanity is at stake, there is no point debating the opportunity to increase density (which is key for compactness) of cities.

With this debate, however, we propose to discuss this normative ideal. Three main themes are being developed. The first is the politics of densification. All the essays address some of the political, social and economic stakes of densification. Within this introduction, we will stress the plasticity of the environmental arguments favouring densification. In fact, the idea that the dense city is more sustainable than the low-density city can be contested on environmental grounds. This plasticity of the environmental discourse makes it all the more obvious to consider densification as a political process favouring some interests while disadvantaging others. In any case, smart growth and new urbanist models are eagerly supported by many land developers, builders and local political elites favouring growth.

The second dominant theme of this debate is how and why morphology matters. For reasons that will be developed in this introduction and in the essays, discussing density will not suffice to qualify changes related to densification. Density is a poor predictor of urban forms; a development consisting of terraced houses may, for example, have the same density as a modernist estate of tower blocks.

The third and last dominant theme is the diversity of suburban densification regimes. It is not only the landscapes of the suburbs that are diverse, but also the local bodies governing them. Between the small residential municipalities of the Paris periurbs and the large inner suburbs of Toronto lies a broad spectrum. 
Figure 3: A barre in Montfermeil: the building is a condominium and a process of acquisition by individual residents is underway (photo by Eric Charmes)

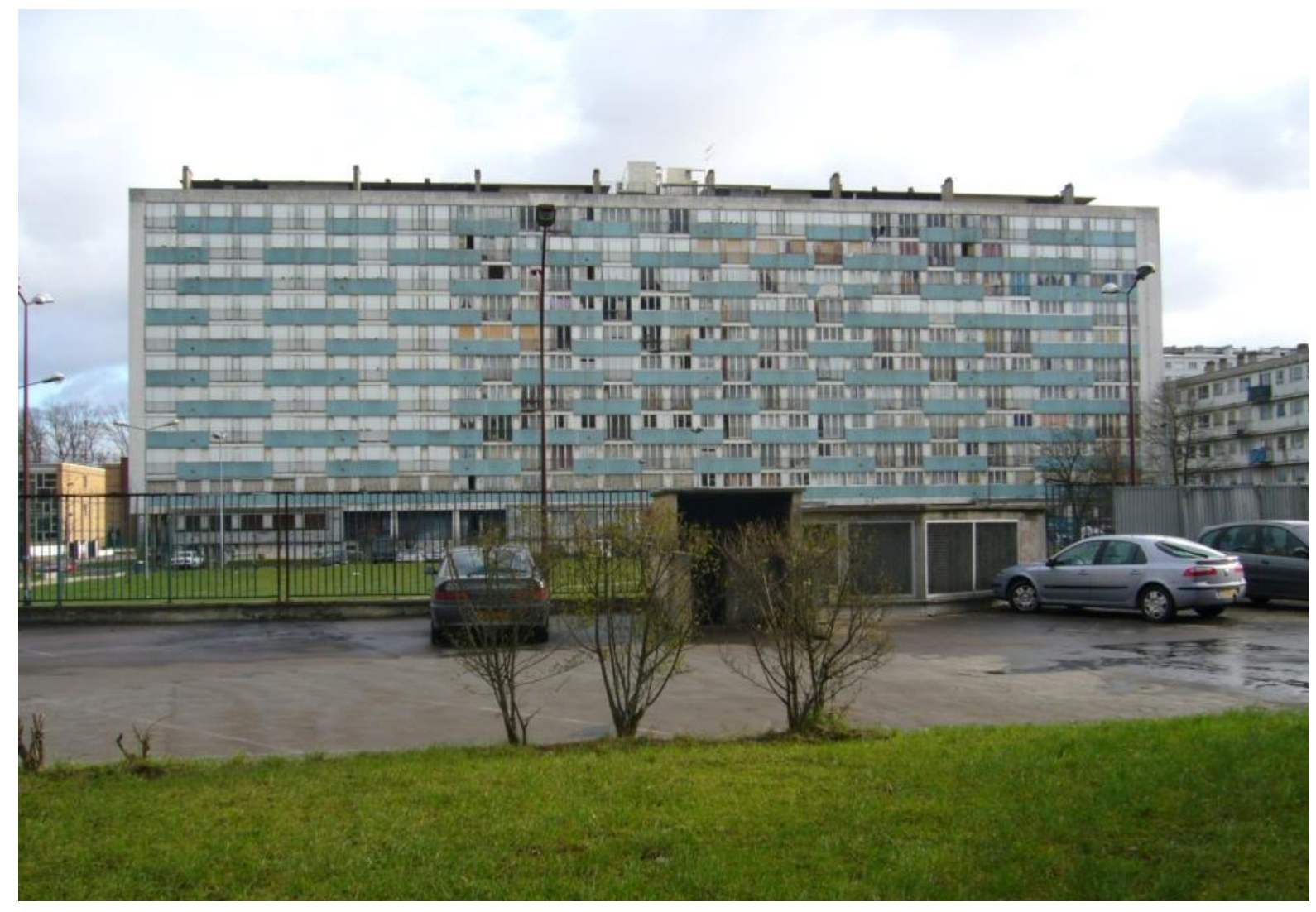

The debate presented here develops these considerations from four case studies, two in Canada and two in France. This is fortuitous, the result of encounters between participants in two research projects (a French project on urban change in low-density residential areas and the Global Suburbanisms project, a globally scaled Canadian study) ${ }^{2}$. Moreover, by focusing on Canada and France respectively, we are not arguing that such a comparison is entirely new, nor are we ignoring the wealth of literature that exists in each country on processes of suburban diversification and change. Yet the comparison of France and Canada is highly relevant, especially in a context where US case studies have largely dominated the Anglophone (and indeed other) literatures. What the US tells us about the suburbs and post-suburbs is relevant for other countries, including Canada and France. Moreover, global dynamics exist and we can in fact talk about the phenomenon of 'global sprawl' (Keil, 1994). Yet each national context gives a specific flavour to suburbanization. And since the focus of this debate is on the politics of densification specifically, Canada and France are two interesting cases to discuss and to compare with the US case, as the societal conditions differ significantly and the variegations of (neoliberal) social formations matter in terms of (post-)suburban outcomes. Indeed, we can detect a Wacquantian landscape of difference: 'In this sense, Canada/Toronto is located in the mid-range of a scale in which France/Paris and USA/ Chicago are extremes. This has to do as much with the traditionally mixed social and capitalist economy in Canada as with the particular nature of neoliberalization in that country' (Young and Keil, 2014: 1594). These differing political histories translate into different representations of the suburbs. Low-density residential suburbs are numerous in France for example, and combating sprawl is a central focus of public policies and debates. Yet the dominant image of the suburb is not

\footnotetext{
${ }^{2}$ See http://www.yorku.ca/suburbs.
} 
associated with individual detached houses. In France, the word banlieues (which translates to suburbs in English) evokes images of apartment towers and barred windows (see Figures 3 and 4) rather than a grid-like alignment of detached single-family dwellings, and images of marginalized immigrant populations rather than a white middle-class community fully integrated into the economy. As explained by Max Rousseau (2015, this issue) in the first part of his essay, this image can be explained by the particular role played by the French state in the production of the city. In Canada too the suburbs are not homogeneous neighbourhoods of single-family homes, instead largely comprising higherdensity morphological forms of comprehensive socio-economic and ethno-cultural diversity (see below). The contributors to this debate are building on a robust literature in Canada that has specifically explained the country's suburbanization through its historical-geographical diversity (see e.g. Harris, 1996; 2004; Walks, 2006; 2007; 2008; Addie et al., 2015; Keil et al., 2015).

Finally, the four essays to follow in this debate focus on transformations in residential space. This choice is, above all, practical: by limiting the diversity of cases, we facilitate significant comparisons (although the terrains under investigation were limited to two countries). That said, this choice is not meant to reduce the suburbs to their residential status. As is well documented, the suburbs do not consist of housing alone. For quite some time, they have brought together employment, commerce, cultural organizations, infrastructural and logistical facilities, ecological spaces (parks and greenbelts) and large-scale institutions such as hospitals and universities. These changes are at the very heart of the move from suburbanization to post-suburbanization.

Figure 4: Toronto tower neighbourhood: Thorncliffe Park (photo by Roger Keil)

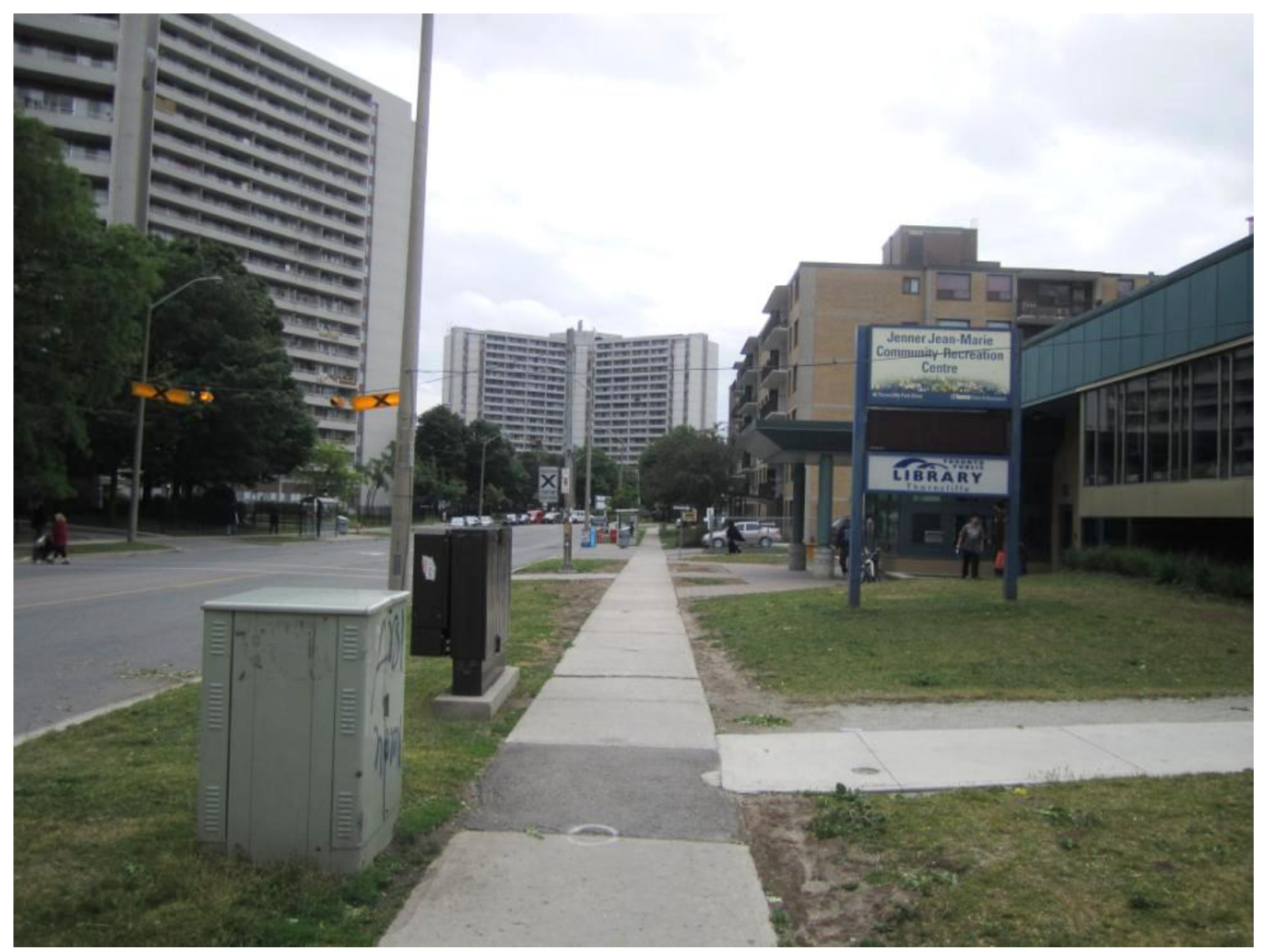




\section{The politics of densification: towards sustainable cities or the new guise of growth coalitions?}

The debate presented here focuses on densification. Densification is by no means the only morphological change that affects suburbs and post-suburbs, but it is certainly among the most discussed strategies within the planning community. The densification of residential suburbs is commonly considered a key objective. It is evidenced in France by the so-called 'Grenelle 1 et 2 de l'environnement' legislation, enacted in 2009 and 2010. Grenelle 2, for example, permits a minimum level of density, especially in areas close to public transport links. Such dispositions are almost unopposed, either from the left or from the right (at least at national level). In the next section of this introduction, we present the politics behind this consensus in favour of densification. As we will see, much recent research points towards a questioning of the relationship between density and sustainability. A re-politicization of the anti-sprawl discourse within urban planning can be expected from this turn in the debate.

Figure 5: New urbanist development in Markham, Ontario (photo by Roger Keil)

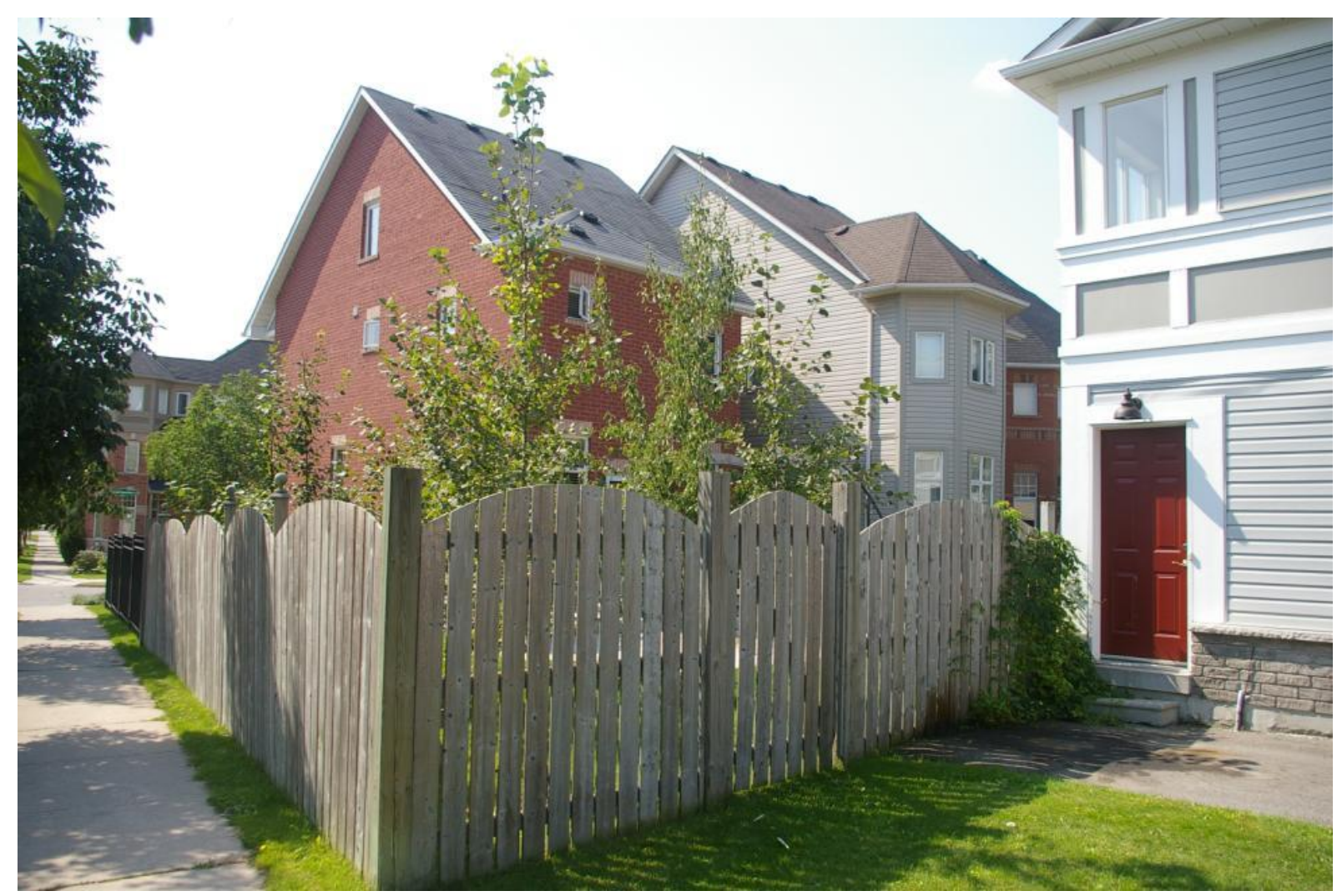

The density turn within the environmentalist discourse

In the 1970s, an ecologist was often someone who escaped the city and its pollution; in the 1980s, however, a reversal occurred with respect to the environmental discourse and the city. This can be symbolized by the success of the work of Peter Newman and Jeffrey Kenworthy (1999), who popularized the simple equation that a dense city was a sustainable city (Charmes, 2010a). Living in a lower-density environment, attractive for its greenness, usually means being far from the concentrated resources of a city and depending on the car for even the shortest trips. More energy is 
consumed and this lifestyle therefore has a negative effect on the environment. This critique of car dependency reinforced previously expressed critiques. In both France and Canada, leapfrog development has since the 1970s been perceived as a threat to agriculture. A related but different criticism focuses on excessive land consumption driven by individual housing. Lastly, a more economistic critique (yet one often integrated with ecological discourse) highlights the cost of sprawl, since the more spread out the city is, the longer its networks and infrastructures need to be (see Sewell, 2009 for a typical summary of those arguments in the Canadian case; Jaglin, 2010 in respect of France).

Fostered by these arguments, the war against sprawl mobilizes most urbanists and planners (in both France and Canada) and most of them now ideologically favour dense and compact cities (planning history in the twentieth century shows that this was not always the case-see Touati, 2010). Critics of low-density residential spaces foster the diffusion of now well-established planning norms like: densification of residential neighbourhoods (see Figure 5); infill on brownfield sites (see Figures 6 and 7); functional diversification (with the development of businesses and employment within a polycentric pattern); and concentration of urban development around train stations and public transport nodes. In any case, the anti-sprawl discourse questions the traditional suburban pastoral ideal of subdivisions and detached single-family dwellings.

Figure 6: Infill at former industrial site in eastern Toronto inner suburb of Scarborough (photo by Roger Keil)

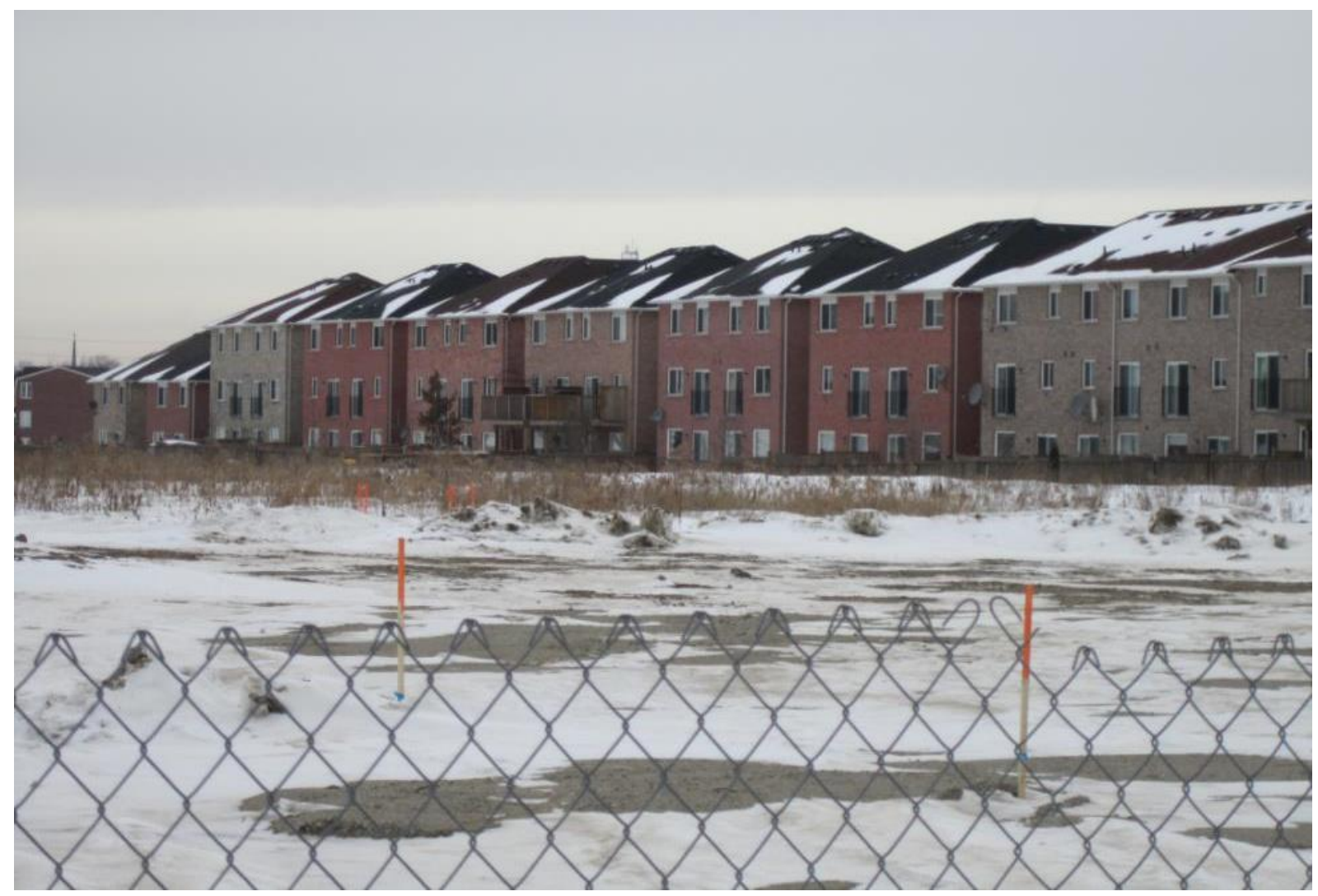

Living in a low-rise residential space is no longer perceived as being about getting closer to the countryside, rather it is deemed unfriendly to the environment. Yet the arguments behind this reasoning are debatable. There is insufficient space here for a comprehensive discussion, but recent 
research has shown that many of the arguments presenting the dense city as more sustainable are at best questionable (see e.g. Echenique et al., 2012). In their assessment of energy consumption in transportation, Newman and Kenworthy (1999) only take daily trips into consideration, ignoring longdistance trips (for pleasure or business). Yet the latter increase with higher densities, due among other things to the need for respite from the noise and stress of dense city centres (Holden and Norland, 2005; Nessi, 2012). More research needs to be undertaken to evaluate the impact of such compensatory trips, but it is significant and severely reduces the presumed advantages of density regarding energy consumption in transportation. Transportation is not the only source of energy consumption in cities. Buildings are also a major one. Yet if the energy consumption of a group of buildings tends to decrease with density, pre-existing detached houses are much more adaptable than high-rise buildings, and it is easier to reduce energy consumption of the former (by installing heat pumps, wells or solar panels). Regarding land consumption, countries like France and Canada do not lack space for urbanization. In France, if every household were to live in a detached house on a 1,000 m2 lot, only about $10 \%$ of the nation's land mass would be urbanized (Charmes, 2013). For the preservation of natural land and agriculture, the issue is less about limiting sprawl, and more about organizing it and controlling so-called leapfrog development.

We could go much further. By raising these points of discussion, our intent is certainly not to advocate sprawl, as for example Robert Bruegmann (2006) did. Nor do we fall in line with the conventional suburb-boosting arguments, emanating usually from American libertarian scholars and pundits (Cox, Kotkin and Richardson for example) who identify classical suburbanization with the promises of the 'American dream'. Density has many other advantages beyond environmental ones, especially for urbanity, serendipity, creativity and so on. Our intent is rather to point to the normativity of the environmental discourse in favour of density. In a context of energy scarcity and global climate change, density appears to be a non-disputable issue, a 'given' beyond political debate. Yet it is not, and density should be re-politicized.

\section{Density = sustainability: the new motto of growth coalitions?}

These scientific uncertainties about the real environmental benefits of density show how important it is for research on the transformation of the suburbs to distance itself from the planning discourses on sprawl. This is all the more important at the metropolitan level, where environmental interests of densification and limitation of sprawl are most disputable. Even if the dense city proves to have some climate change virtues, these may only be apparent at the international level. Worse, the inhabitants of the densified areas will suffer from increased exposure to local pollution (Echenique et al., 2012). At the metropolitan scale, other than an uncertain improvement of the local environment the stakes of urban redevelopment reside, for example, in: the mobilization of scarce land resources for new construction; improving the image of socially distressed neighbourhoods (an image that looms over the city itself ); and the growth of the metropolis.

Indeed, the density turn within environmental discourse is especially convenient for promoting projects of growth coalitions or (more fundamentally) urban growth, and often serves to override local resistance. In many suburbs, residents expect that their representatives seek to protect the environment, preserve quality of life and limit growth, rather than attract new jobs or homes. Of course, everything depends on the context, but the general trend is one of decline in positions favourable to growth. In the light of that, the density turn helps to counter the main arguments used by movements opposed to urban growth, especially in recent cases of new-build gentrification. It helps to dismiss any desire to preserve the original programme of suburban utopias, such as low-density 
built-up areas, as local expressions of selfishness. And it helps to discredit and delegitimize local mobilizations by designating them as nimbyism (Wolsink, 2006). More broadly, the density turn helps to weaken local opposition to growth from its own environmental perspective. By referring to the future of the planet, one can justify the densification of suburbs in the name of sustainable development and denounce opposition to local intensification projects as self-serving.

Figure 7: Redevelopment of former industrial land in Plaine Saint-Denis, close to Paris city limits (photo by Eric Charmes)

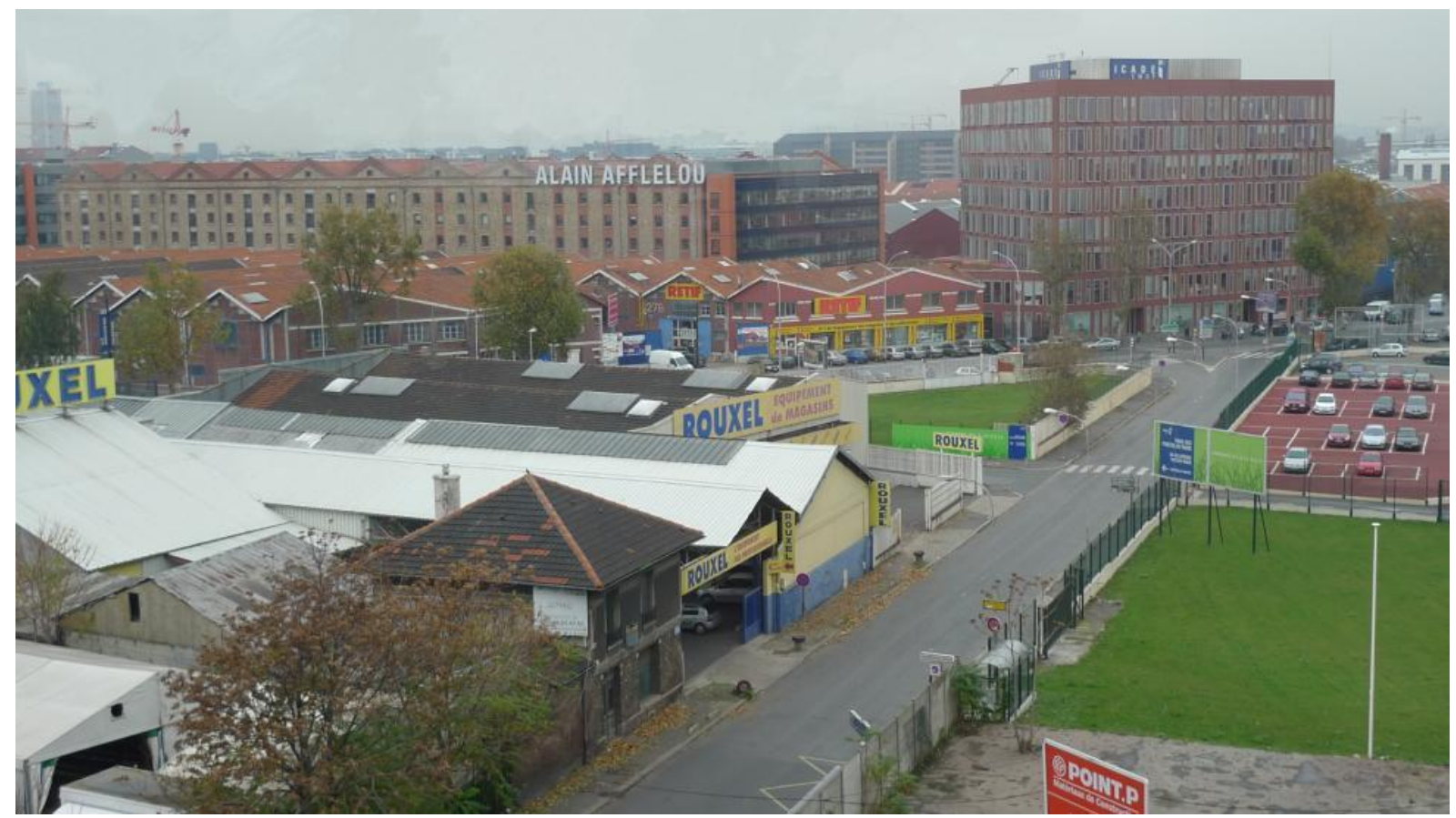

Such disqualification of local opposition to growth is questionable. In fact, behind the motivations associated with sustainable development, and more specifically behind the equation that density equals a sustainable city, often hides the old conflict between exchange value and use value (Logan and Molotch, 2007 [1987]). The defensive politics of suburbanites vis-à-vis continuous development is not just a defensive stance of private interests; 'such a politics also recognizes the constraints of the jumbled, anaesthetic environments [of post-suburban in-between cities] as the true playgrounds of a new and potentially productive politics of the urban region' (Keil and Young, 2011: 77). Within that politics, citizens have learned to suspect other special interests behind the positions put forward. Thus, the idea that growth is good for a local community is often obliterated by the notion that this growth serves the interests of developers (growth is greed, to put it bluntly). From this point of view, defending one's suburban 'castle' against higher density is perceived by observers to be a defence by 'the little guy' against the greed of developers and those financing their projects. This local perspective appears all the more legitimate since there is a growing interest in local policymaking processes, in conjunction with the rise of participatory forms of democracy.

Last but not least, local opposition to growth is successful precisely because it is not reduced to expressions of local selfishness, and is able to make its views resonate with issues that go beyond the local (Keil and Ronneberger, 1994). For that matter, such opposition is often associated with the use of environmental arguments: new construction is not only bad for house values, it is also bad for the 
environment. Without necessarily adhering to those ideologies, many citizens leverage environmental concerns to serve their local interests.

All this confirms that environmental arguments are particularly plastic. And two of the central terms of this debate below, sustainability and density, are themselves 'chaotic terms'. They can be used to support growth as much as to justify stopping or limiting growth. They can justify the fight against urban sprawl, while justifying the purchase of a house with a large garden on the outskirts of a city. This plasticity, coupled with the ability of environmental arguments to generate consensus, creates legitimizations that are often used to defend projects or initiatives, which are actually determined by other agendas. It is therefore necessary to analyse and critique these issues. In short, the morphological changes of suburbs must be analysed as much as those faced by urban centres. These transformations bring with them political and social issues.

\section{Morphology matters: deconstructing densification}

If suburbs are ever-less frequently called suburbs, but zwischenstadt, in-between cities or post-suburbs instead, it is primarily because many so-called suburbs do not look like dormitory towns with their agglomeration of detached houses. Yet those morphological changes are rarely considered in and of themselves, but instead as signs or symptoms of something else, like structural modifications of daily mobility, changes in suburban politics, redefinition of metropolitan centrality and so on (Phelps

and $\mathrm{Wu}, 2011 \mathrm{~b})$. Within this framework, a new multi-storey building in a low-density suburb manifests among other things the evolution of the position of that suburb within a metropolitan system. More generally, it manifests that some quintessential attributes of centrality are now to be found within suburbs. Yet density matters not only as a signifier or as a symbol, but as an important component of the production of the city. Through the various forms it may take, density reveals power relations. It also mediates between different interests, favouring some and disadvantaging others.

As Figure 8 shows, density can take many different forms. A comparable number of houses or square metres can take many different forms. And those different forms have political and social meaning. Thus (and this is what we are debating here), it remains to be understood why a multi-storey building emerges in one particular suburb and not in another one; why the densification process should take the form of a multi-storey building and not of infill semi-detached or terraced houses. These questions are discussed below by Anastasia Touati (2015, this issue), who contrasts hard and soft densification (see also Touati, 2013). She makes the illuminating statement that soft densification can be a compromise between exchange value and use value. In a low-density residential neighbourhood, the addition of individual houses through infill is a way of reconciling economic interests emergent from urban growth with the interests of the inhabitants, since the residential image of the neighbourhood is preserved. Soft densification can indeed overcome resistance from inhabitants, while hard densification may trigger strong opposition. Yet, soft densification may not be sufficient to sustain a strategy seeking to establish a suburb as a metropolitan sub-centre. In this sense, the type of densification is revealing of power relations, particularly between local and metropolitan interests. 
Figure 8: Morphological modulations of density. In all those three cases, the density of construction is the same (source: Institut d'aménagement et d'urbanisme de l'île-de-France, 2005; Appréhender la densité, Note Rapide, 383)

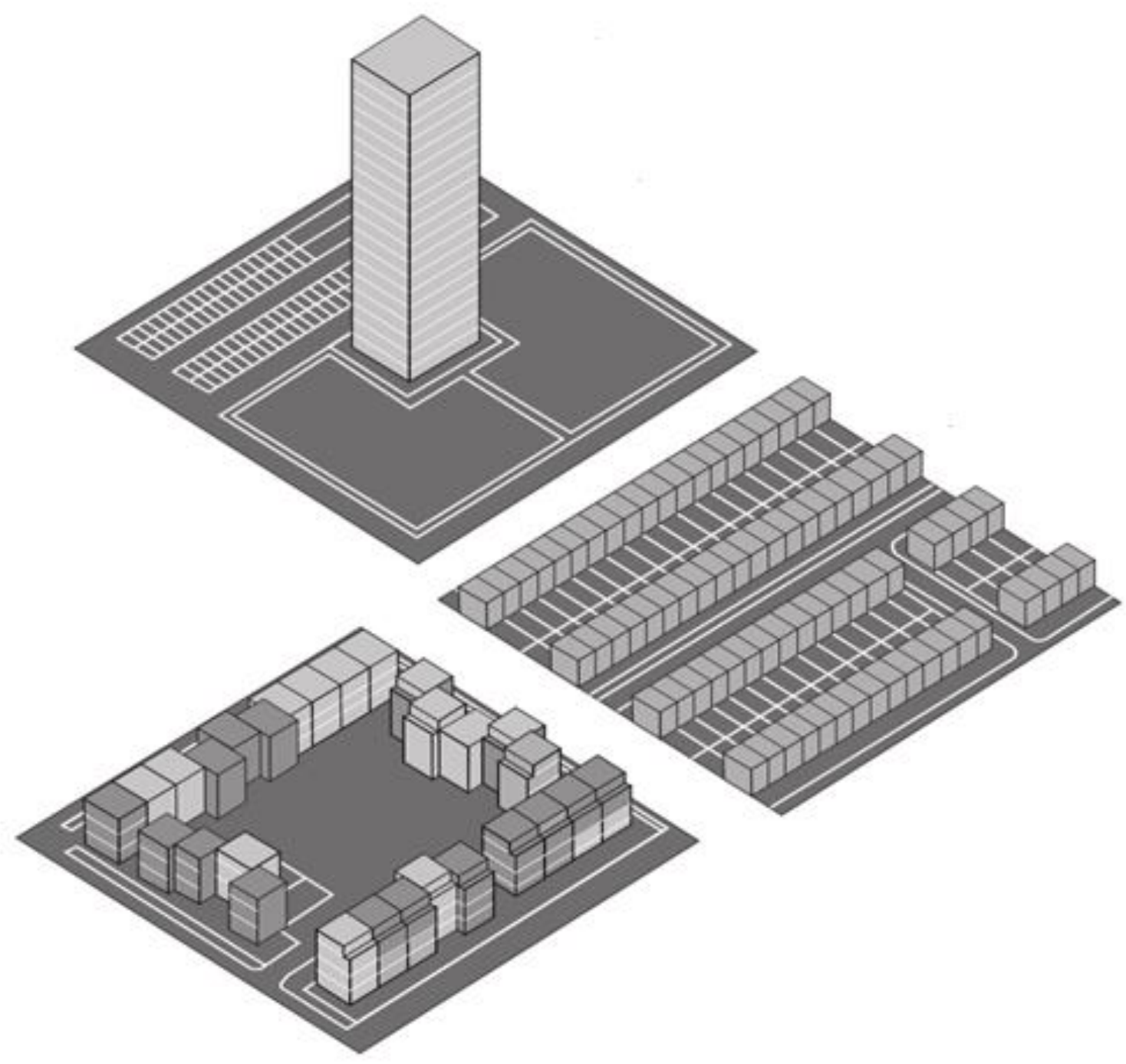

Other interesting questions addressed in this debate are: which are the social groups that densification policies aim to attract, and who are those coming to inhabit the new building. Indeed, as shown by Max Rousseau (this issue), densification may (depending upon local context) be part of a process of social downgrading as well as a process of upgrading. In an upscale residential suburb, the construction of a multi-storey building is perceived as a threat, both from the perspective of landscape conservation and from the perspective of social engineering. The same building on a derelict modernist-era housing estate (the so-called grands ensembles) is on the contrary perceived as a way of rehabilitating the place and attracting middle-class households.

In this debate, two out of the four essays-those of Will Poppe and Douglas Young and of Max Rousseau-focus on large modernist housing estates. As stated above, in France the image of the suburb (banlieue) is less associated with the single-family home (pavillon), and more with the grands ensembles, and thus towards verticality and concrete rather than horizontality and greenery. This image of the suburbs contrasts sharply with the dominant one in North America, even if Canadian cities are renowned for high-rise neighbourhoods that are often found at the urban periphery. 
Particularly relevant to the debate presented here, the French grands ensembles are the object of a policy focusing on morphology. Between 1954 and 1973, millions of new homes were built in grands ensembles. For various reasons we cannot present in detail here (see Tissot, 2008), the grands ensembles are today the places where France's urban crisis is concentrated, places like Clichy-sousBois and Montfermeil, municipalities in the Paris suburbs that were at the epicentre of the 2005 riots (Dikec, 2007; Figure 3). These incidents drive public intervention, and significant public funds have been mobilized. This intervention is largely morphological: it targets towers and housing blocks that 'disfigure' the landscape, focusing on the image of 'concrete neighbourhoods', and it reconstructs a habitat of more traditional (low-rise) urban forms, which is supposed to appeal to the middle classes. It is also said that the grands ensembles should be 'de-densified'. Indeed, the French grands ensembles are often associated with hyper-density, and their repugnant image is regularly mobilized by those opposing densification (many French grand ensembles technically have the same density as a town core made up of terraced houses with small gardens, but what matters is the size of individual buildings).

This focus on morphology may be related to the French state's poor capacity to trust the people, especially those from immigrant backgrounds (Bacqué and Sintomer, 2004; Baudin and Genestier, 2006). The comparison with Canada is telling. While Canada shares with France a built environment of peripheral high-rise housing estates that have become concentrations of poor, immigrant, non-white tenant populations, the (Anglo-)Canadian urban experience also includes communitarian recognition, through the institutions of a multicultural society which provides safeguards against some of the problems associated with the exclusionary tendencies embedded in the republican tradition. While no federal urban policy exists, the Canadian (local) state has institutionalized integrationist measures, some of them place-based, allowing for targeted interventions through a variety of mechanisms: schools, community welfare, culture, etc. ${ }^{3}$

In the case of Toronto, renewal of residential areas in the inner suburbs has focused in recent years on what has been termed tower renewal (see Figure 4). Discussed at greater length in the essay below by Will Poppe and Douglas Young, this process has been seen as an attempt not only to apply architectural and energy retrofits to existing concrete towers, but also to re-engineer entire tower neighbourhoods. This has been part of a general place-based strategy targeting 13 so-called 'priority neighbourhoods', selected (for both socio-demographic and built-form reasons) as concentration points for social policy interventions. While the discourse around concrete towers and the communities inhabiting them resembles the negative practices found in France, there has also been considerable movement by urban specialists and residents alike to rehabilitate rather than demonize these high-rise suburbs. Many initiatives and projects specifically seek to empower residents of these neighbourhoods and overcome the negative images associated with their environment.

In any case, morphological changes do not happen easily in the suburbs. They can be hindered by many factors. Some have already been mentioned, but a fact often overlooked outside the inner circle of urban designers and planners is that one of the biggest obstacles to change in suburban housing estates (be they high-rise buildings or detached houses) is their functional specialization. Suburbs were built as dormitory areas. As documented in Pierre Filion's essay below, functional specialization is one of the main causes of inertia in suburban landscapes, however dated that may seem. What remains prevalent is the morphological structure of the suburban street and road network that became predominant in the second half of the twentieth century. Throughout that period, all the planning manuals recommended the environmental area model, to preserve low-density residential areas from

\footnotetext{
${ }^{3}$ Canada and France have an unfortunate shared experience in terms of their marginalized suburban populations.
} 
the nuisance of through traffic. According to the creator of the concept, Colin Buchanan (1963), environmental areas should be designed so as to have no extraneous traffic, no drifting through of traffic without business in the area, which should be accessible from arterial or distributor roads at one intersection only (see Figure 9). These environmental areas are highly favourable to functional specialization: there is only one type of user, the resident. Those who access the space do so either as residents or as visitors of the residents. Of course, functional specialization is not inherent to environmental areas: mono-functional zoning is a planning decision that can be made relatively independently from the design of the road system. Yet, a comparison of how residential suburbs structured along a gridded street system evolve, and how suburbs structured along pods develop, shows that the former are much more open to functional mixing than the latter. In fact, the dense and multifunctional city is facilitated where there are flows of pedestrians, cars, etc. (Mangin, 2004; Charmes, 2010b). The organization of the urban fabric within a collection of enclaves where all traffic is excluded prevents this activation of land by circulatory flows.

Figure 9: The 'environmental area' principle, as conceived by Colin Buchanan (1963: 69)

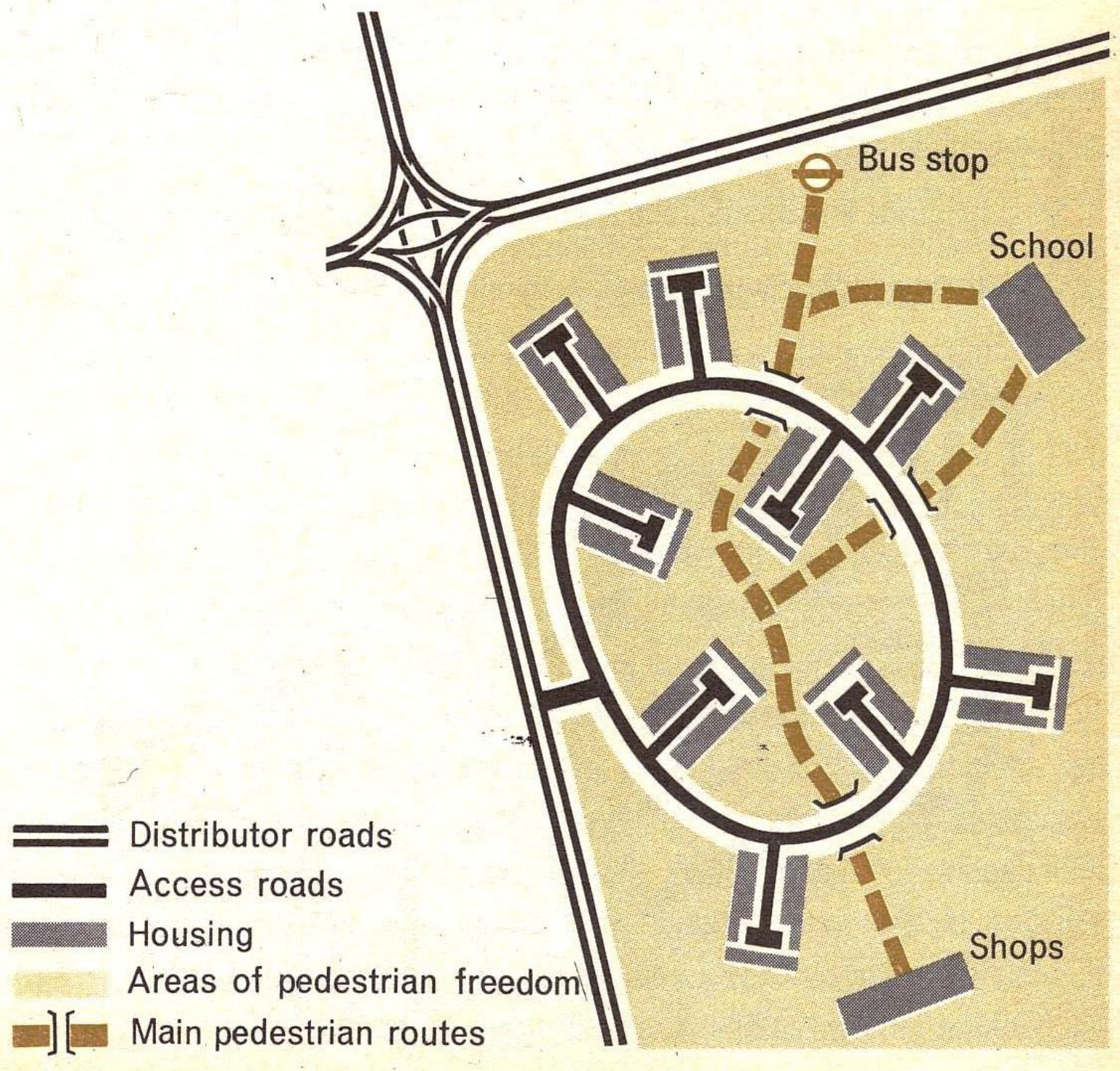


Since the road and street networks, as well as the underlying infrastructures such as water and sewerage, exert very strong inertia in the cities, circulation flows in many suburbs will remain separated from urban life for generations to come. And the transformation of the suburban landscape must happen within that framework, which means that often densification happens and will happen without functional diversity or, more accurately, with limited functional diversity. The low-rise office park perhaps changes into a high-rise office park, not into a dense multifunctional urban centre like those of Lyon, Toronto or Paris. This is one of the major reasons why the densification processes occurring in many suburbs produce a landscape that is very different from that found in older urban centres. This is why many suburbs are turning into post-suburbs and not into urban centres. Of course, suburbs include older towns and cities which can become denser through functional diversity, but those towns and cities do not constitute the major part of suburban landscapes.

\section{Densification regimes}

Factors hindering or promoting densification are present in almost all circumstances. However, they exist in varying degrees. Variations occur from one country to another depending on the particular urban history, attitudes towards nature and density, and systems of local government. For example, the idea that density or, more broadly, that the dense city is collectively desirable may historically have been a more accepted notion in France than in Canada (yet it is also obvious that there are convergences here: Canadians have learned to accept the diktats of a climate-change-driven push towards greater compactness; and French suburbanites have learned to escape the grands ensembles, gravitating towards the lotissements of pavillons on the outskirts of not only large conurbations but also many smaller towns and villages, generating a pervasive pattern of leapfrog development similar to that found in many North American cities). Variations are also observed within a single city. This is illustrated well in the essay by Max Rousseau (this issue): the capacity of households living in lowincome areas to protect their quality of life is not the same as that of affluent households (primarily because low-income households are less able to mobilize legal or other means to challenge development projects). In addition, as stated above, municipalities with poor populations are often motivated to transform the urban landscape, whereas richer municipalities do not have this same desire.

These are only a few cases from a broad variety. The diversity of reactions to the dynamics of change in suburban morphology reflects the diversification of governmental regimes in suburbs and postsuburbs, with each being more or less favourable to certain coalitions and particular morphological changes (Phelps and Wood, 2011). These suburban regimes are formed among actors with varying levels of status and intervention capacity. We propose an overview of that diversity in Tables 1 and 2, which should help readers make the fullest sense of the four essays comprising this debate (especially those based on case studies). The tables are based on the knowledge of the authors, acquired both through fieldwork and from the literature. Due to space constraints, our accompanying commentary is brief. 
Table 1: Diversity of post-suburban regimes in France

\begin{tabular}{|c|c|c|c|c|}
\hline Suburbs type & Population type & Dominant politics & $\begin{array}{l}\text { Main actors } \\
\text { (inhabitants) }\end{array}$ & $\begin{array}{l}\text { Morphological } \\
\text { change }\end{array}$ \\
\hline \multirow{4}{*}{$\begin{array}{l}\text { Inner and } \\
\text { middle ring } \\
\text { suburbs } \\
\text { (the farther } \\
\text { from the core } \\
\text { city the less } \\
\text { intense the } \\
\text { changes) }\end{array}$} & Upper class & $\begin{array}{l}\text { Exclusionary zoning; } \\
\text { occasional local } \\
\text { redevelopment } \\
\text { projects }\end{array}$ & $\begin{array}{l}\text { Municipality }(10,000 \mathrm{~s} \\
\text { up to } 100,000)\end{array}$ & $\begin{array}{l}\text { Stability with local } \\
\text { sporadic changes }\end{array}$ \\
\hline & $\begin{array}{l}\text { Diverse with a } \\
\text { domination of } \\
\text { middle classes }\end{array}$ & $\begin{array}{l}\text { Redevelopment } \\
\text { projects of various } \\
\text { sizes }\end{array}$ & $\begin{array}{l}\text { Municipality }(10,000 \text { s } \\
\text { up to } 100,000) ; \\
\text { metropolitan } \\
\text { community (including } \\
\text { core city)*; } \\
\text { developers }\end{array}$ & $\begin{array}{l}\text { Densification } \\
\text { (mostly soft); brown } \\
\text { field } \\
\text { redevelopment; new } \\
\text { offices; } \\
\text { sporadic } \\
\text { transformations }\end{array}$ \\
\hline & $\begin{array}{l}\text { Diverse with a } \\
\text { domination of } \\
\text { lower and lower } \\
\text { middle classes }\end{array}$ & $\begin{array}{l}\text { Redevelopment } \\
\text { through gentrification } \\
\text { (including new build } \\
\text { gentrification) }\end{array}$ & $\begin{array}{l}\text { Municipality }(10,000 s \\
\text { up to } 100,000) ; \\
\text { metropolitan } \\
\text { community (including } \\
\text { core city)*; } \\
\text { developers }\end{array}$ & $\begin{array}{l}\text { Densification (soft to } \\
\text { hard), brown field } \\
\text { redevelopment; new } \\
\text { commercial } \\
\text { infrastructure; new } \\
\text { offices }\end{array}$ \\
\hline & $\begin{array}{l}\text { Poor (with } \\
\text { many } \\
\text { immigrants) }\end{array}$ & $\begin{array}{l}\text { Urban renewal } \\
\text { through partial } \\
\text { demolition }\end{array}$ & $\begin{array}{l}\text { Municipality } \\
(10,000 s) ; \\
\text { metropolitan } \\
\text { community (including } \\
\text { core city) }{ }^{*} \text {; national } \\
\text { State ; large } \\
\text { developers }\end{array}$ & $\begin{array}{l}\text { From modernist to } \\
\text { neotraditional }\end{array}$ \\
\hline \multirow[t]{2}{*}{$\begin{array}{l}\text { Edge cities: } \\
\text { new towns } \\
\text { (mostly around } \\
\text { Paris and Lyon) }\end{array}$} & \multirow[t]{2}{*}{$\begin{array}{l}\text { Diverse without } \\
\text { upper middle } \\
\text { nor upper } \\
\text { classes }\end{array}$} & $\begin{array}{l}\text { Extensive growth } \\
\text { from the 1960s; } \\
\text { redevelopment from } \\
\text { the 1990s }\end{array}$ & $\begin{array}{l}\text { National State; } \\
\text { several municipalities } \\
(100,000 \text { s); } \\
\text { large developers }\end{array}$ & $\begin{array}{l}\text { Extensive growth } \\
\text { ending or slowing } \\
\text { down; } \\
\text { renewal in some } \\
\text { neighbourhoods }\end{array}$ \\
\hline & & $\begin{array}{l}\text { Preserving their } \\
\text { influence over their } \\
\text { surroundings }\end{array}$ & $\begin{array}{l}\text { Municipality } \\
(10,000 \text { s); developers }\end{array}$ & $\begin{array}{l}\text { Renewal in some } \\
\text { neighbourhoods; } \\
\text { extension of the } \\
\text { urbanized area } \\
\text { through } \\
\text { subdivisions; } \\
\text { business parks; } \\
\text { shopping strips }\end{array}$ \\
\hline $\begin{array}{l}\text { Periurbs: } \\
\text { residential } \\
\text { municipality } \\
\text { (first periurban } \\
\text { rings) }\end{array}$ & $\begin{array}{l}\text { Middle to upper } \\
\text { middle classes } \\
\text { with a marked } \\
\text { homogeneity at } \\
\text { the municipal } \\
\text { level }\end{array}$ & $\begin{array}{l}\text { No growth; } \\
\text { exclusionary zoning; } \\
\text { clubbisation }\end{array}$ & $\begin{array}{l}\text { Municipality } \\
\text { (typically } 1,500 \text { ) }\end{array}$ & $\begin{array}{l}\text { Stability with } \\
\text { occasional } \\
\text { redevelopment of } \\
\text { old village core }\end{array}$ \\
\hline $\begin{array}{l}\text { Towns } \\
\text { (about } 10 \% \text { of } \\
\text { the periurban } \\
\text { municipalities) }\end{array}$ & $\begin{array}{l}\text { Diverse (within } \\
\text { middle classes) }\end{array}$ & $\begin{array}{l}\text { Extensive growth } \\
\text { and/or } \\
\text { redevelopment of } \\
\text { town center (the } \\
\text { closer from the core } \\
\text { city the less extensive }\end{array}$ & $\begin{array}{l}\text { Municipality } \\
\text { (typically between } \\
3,000 \text { and 10,000); } \\
\text { developers }\end{array}$ & $\begin{array}{l}\text { Subdivisions; new } \\
\text { business parks; new } \\
\text { suburban shopping } \\
\text { strips; densification } \\
\text { of town center }\end{array}$ \\
\hline
\end{tabular}




\begin{tabular}{|l|l|l|l|l|}
\hline \multirow{2}{*}{ Fringes } & $\begin{array}{l}\text { growth and the more } \\
\text { redevelopment) }\end{array}$ & $\begin{array}{l}\text { Extensive growth } \\
\text { (relatively to the size) } \\
\text { class; rural poor }\end{array}$ & $\begin{array}{l}\text { Municipality (1,000 } \\
\text { and less); } \\
\text { small developers and } \\
\text { builders }\end{array}$ & $\begin{array}{l}\text { Houses build by } \\
\text { individual } \\
\text { landowners; small } \\
\text { subdivisions } \\
\text { (typically 20 } \\
\text { detached houses per } \\
\text { subdivision) }\end{array}$ \\
\hline
\end{tabular}

* except for Paris (a "Métropole du Grand Paris" will be established in 2016 however)

Table 2: Diversity of post-suburban regimes in Canada

\begin{tabular}{|c|c|c|c|c|}
\hline Suburbs type & Population type & Dominant politics & Main actors & $\begin{array}{l}\text { Morphological } \\
\text { change }\end{array}$ \\
\hline \multirow[t]{3}{*}{$\begin{array}{l}\text { Inner and } \\
\text { middle ring } \\
\text { suburbs (In- } \\
\text { between } \\
\text { cities; third } \\
\text { city) }\end{array}$} & $\begin{array}{l}\text { Elite uses in } \\
\text { educational } \\
\text { institutions like } \\
\text { universities; little } \\
\text { residential use by } \\
\text { upper classes }\end{array}$ & $\begin{array}{l}\text { Institutional } \\
\text { redevelopment projects; } \\
\text { capital expenditure into } \\
\text { prestige infrastructures; } \\
\text { highways; in Toronto } \\
\text { specifically: } \\
\text { conservative upper class } \\
\text { appeal through populist } \\
\text { politics to lower and } \\
\text { middle classes that feel } \\
\text { excluded from inner city } \\
\text { political power } \\
\text { perceived as elitist; end } \\
\text { to the 'war on the car' }\end{array}$ & $\begin{array}{l}\text { Universities; state } \\
\text { institutions; } \\
\text { hospitals }\end{array}$ & $\begin{array}{l}\text { Rapid and large } \\
\text { scale change }\end{array}$ \\
\hline & Middle class & $\begin{array}{l}\text { Some infill; some } \\
\text { continuing larger scale } \\
\text { suburbanization through } \\
\text { single family homes, } \\
\text { townhouses, high rise } \\
\text { condominiums; some } \\
\text { gentrification along } \\
\text { emerging transit lines } \\
\text { (subway extension in } \\
\text { Toronto) }\end{array}$ & $\begin{array}{l}\text { Developers; private } \\
\text { households; transit } \\
\text { agencies, park and } \\
\text { sports } \\
\text { organizations }\end{array}$ & $\begin{array}{l}\text { Densification } \\
\text { (mostly soft), } \\
\text { brownfield } \\
\text { redevelopment; } \\
\text { new offices and } \\
\text { warehouses; } \\
\text { conversions of } \\
\text { industrial spaces } \\
\text { into places of } \\
\text { worship; } \\
\text { conversions of } \\
\text { places of worship } \\
\text { into condominiums; } \\
\text { Sporadic } \\
\text { transformations }\end{array}$ \\
\hline & $\begin{array}{l}\text { Lower to lower } \\
\text { middle class }\end{array}$ & $\begin{array}{l}\text { Redevelopment of } \\
\text { tower neighbourhoods } \\
\text { and strip malls through } \\
\text { state action; hesitant } \\
\text { gentrification effects }\end{array}$ & $\begin{array}{l}\text { Local state; } \\
\text { planning and } \\
\text { architecture } \\
\text { professionals; } \\
\text { public housing } \\
\text { agencies (major } \\
\text { landlords in tower } \\
\text { neighbourhoods); } \\
\text { school boards } \\
\text { (agents aiming for }\end{array}$ & $\begin{array}{l}\text { Retrofits } \\
\text { (environmental, } \\
\text { aesthetic and } \\
\text { structural); some } \\
\text { new commercial } \\
\text { infrastructure, new } \\
\text { offices; community } \\
\text { centres in priority } \\
\text { neighbourhoods }\end{array}$ \\
\hline
\end{tabular}




\begin{tabular}{|c|c|c|c|c|}
\hline & & & $\begin{array}{l}\text { social cohesion in } \\
\text { 'priority n'hoods'; } \\
\text { conservation } \\
\text { agencies; new } \\
\text { immigrant } \\
\text { communities; } \\
\text { NGOs and shadow } \\
\text { state actors; place } \\
\text { based policies }\end{array}$ & \\
\hline $\begin{array}{l}\text { Edge city: new } \\
\text { towns }\end{array}$ & $\begin{array}{l}\text { Diverse with } \\
\text { broad spectrum } \\
\text { of middle classes; } \\
\text { often ethnoburbs } \\
\text { (new immigrant } \\
\text { middle classes } \\
\text { from non- } \\
\text { European origins) }\end{array}$ & $\begin{array}{l}\text { Extensive growth from } \\
\text { the } 1960 \mathrm{~s} ; \\
\text { Redevelopment from } \\
\text { the 1990s }\end{array}$ & $\begin{array}{l}\text { Large developers; } \\
\text { emerging suburban } \\
\text { municipalities } \\
\text { (building } \\
\text { spectacular } \\
\text { municipal spaces, } \\
\text { city halls, cultural } \\
\text { facilities, } \\
\text { educational } \\
\text { facilities, } \\
\text { museums, } \\
\text { professional sports } \\
\text { facilities); } \\
\text { immigrant place } \\
\text { entrepreneurs }\end{array}$ & $\begin{array}{l}\text { Extensive growth } \\
\text { qualified by new } \\
\text { growth } \\
\text { management } \\
\text { regime. } \\
\text { Extensive } \\
\text { commercial (malls); } \\
\text { entertainment } \\
\text { (spectacle spaces } \\
\text { and entertainment } \\
\text { parks); and } \\
\text { infrastructural } \\
\text { developments } \\
\text { (private and public } \\
\text { highways; rail-based } \\
\text { transit; transit } \\
\text { corridors); Suburban } \\
\text { condominium hubs }\end{array}$ \\
\hline $\begin{array}{l}\text { Mature } \\
\text { residential } \\
\text { outer suburbs }\end{array}$ & $\begin{array}{l}\text { Middle to upper } \\
\text { middle with } \\
\text { homogeneity at } \\
\text { the municipal } \\
\text { level but } \\
\text { increasingly } \\
\text { target of new } \\
\text { immigration by } \\
\text { diaspora middle } \\
\text { classes from Asia }\end{array}$ & $\begin{array}{l}\text { Managed growth - } \\
\text { Exclusionary zoning }\end{array}$ & $\begin{array}{l}\text { Municipality; } \\
\text { resident } \\
\text { associations }\end{array}$ & $\begin{array}{l}\text { Stability with } \\
\text { occasional } \\
\text { redevelopment of } \\
\text { old village core }\end{array}$ \\
\hline $\begin{array}{l}\text { Sub and - } \\
\text { exurban } \\
\text { towns }\end{array}$ & $\begin{array}{l}\text { Diverse (within } \\
\text { middle classes); } \\
\text { but also growing } \\
\text { poverty among } \\
\text { new immigrants, } \\
\text { older people }\end{array}$ & $\begin{array}{l}\text { Extensive growth with } \\
\text { redevelopment of town } \\
\text { center (the closer to } \\
\text { main urban center the } \\
\text { less extensive growth } \\
\text { and the more } \\
\text { redevelopment) }\end{array}$ & $\begin{array}{l}\text { Municipality and } \\
\text { developers; some } \\
\text { gating and other } \\
\text { private } \\
\text { authoritarian } \\
\text { forms; innovation } \\
\text { in transit (rapid bus } \\
\text { lines, rail) and } \\
\text { spectacular civic } \\
\text { buildings; sports } \\
\text { facilities }\end{array}$ & $\begin{array}{l}\text { New subdivisions, } \\
\text { new business parks, } \\
\text { new suburban } \\
\text { shopping centers, } \\
\text { densification of } \\
\text { town center }\end{array}$ \\
\hline $\begin{array}{l}\text { Exurban } \\
\text { fringes }\end{array}$ & & $\begin{array}{l}\text { Growth tempered by } \\
\text { greenbelt and similar } \\
\text { measures of regional } \\
\text { growth control } \\
\text { (agricultural land } \\
\text { reserves); golf courses, } \\
\text { para-agriculture }\end{array}$ & $\begin{array}{l}\text { Provinces, } \\
\text { municipalities }\end{array}$ & $\begin{array}{l}\text { Some leapfrogging } \\
\text { of development }\end{array}$ \\
\hline
\end{tabular}


The suburban political game is played out through the central modalities of suburban governance on the terrain of local communities, where the state (at various scales), capital accumulation (land development) and authoritarian governmentalities (articulated through politicized class interests) interact (Ekers et al., 2012). In France, the public actor predominates (see Table 1). This corresponds with the prevailing image of France abroad. Yet contrary to that image, the state has lost many of its prerogatives. Remnants of its former power may be glimpsed in places like La Défense or in new towns around Paris, but today the state remains largely in the background (working through national regulations or project funding). The image of a highly centralized country that remains prevalent around the world does not reflect the highly fragmented nature of France's public actors. Municipalities play much more of a key role in suburban regimes than the national state does. Moreover, municipal authorities are extremely fragmented, especially in periurban (or exurban) areas. Inter-municipal cooperation has developed since the turn of the millennium but, as Max Rousseau's essay (this issue) demonstrates, power remains largely in the hand of the municipalities themselves. This results in a strong emphasis on local (sometimes very local) perspectives, focused on the defence of quality of life and residential interests more generally (Charmes, 2011).

Everywhere, residents mobilize to preserve the landscape and maintain certain social qualities of their local communities. Such resistance has become very important, both in North America and in Europe, as evidenced by the literature on nimbyism or no-growth coalitions (Subra, 2007). This resistance represents an extension from the home to the local environment of the domain over which people consider that they have property rights. Householders do not only buy a home, but also the local environment that comes with it. Through that process, the relationship to the neighbourhood becomes more and more similar to one of co-ownership, a process we described as 'clubbisation' (Charmes, 2009). This process is one of the main driving forces powering not only residents' movements, but also the development of private residential neighbourhoods and gated communities. And in the case of France this process has a significant effect on municipalities.

Figure 10: Driving out of a small periurban commune (a territory governed by a municipality) in the first periurban ring of Paris (photo by Eric Charmes)

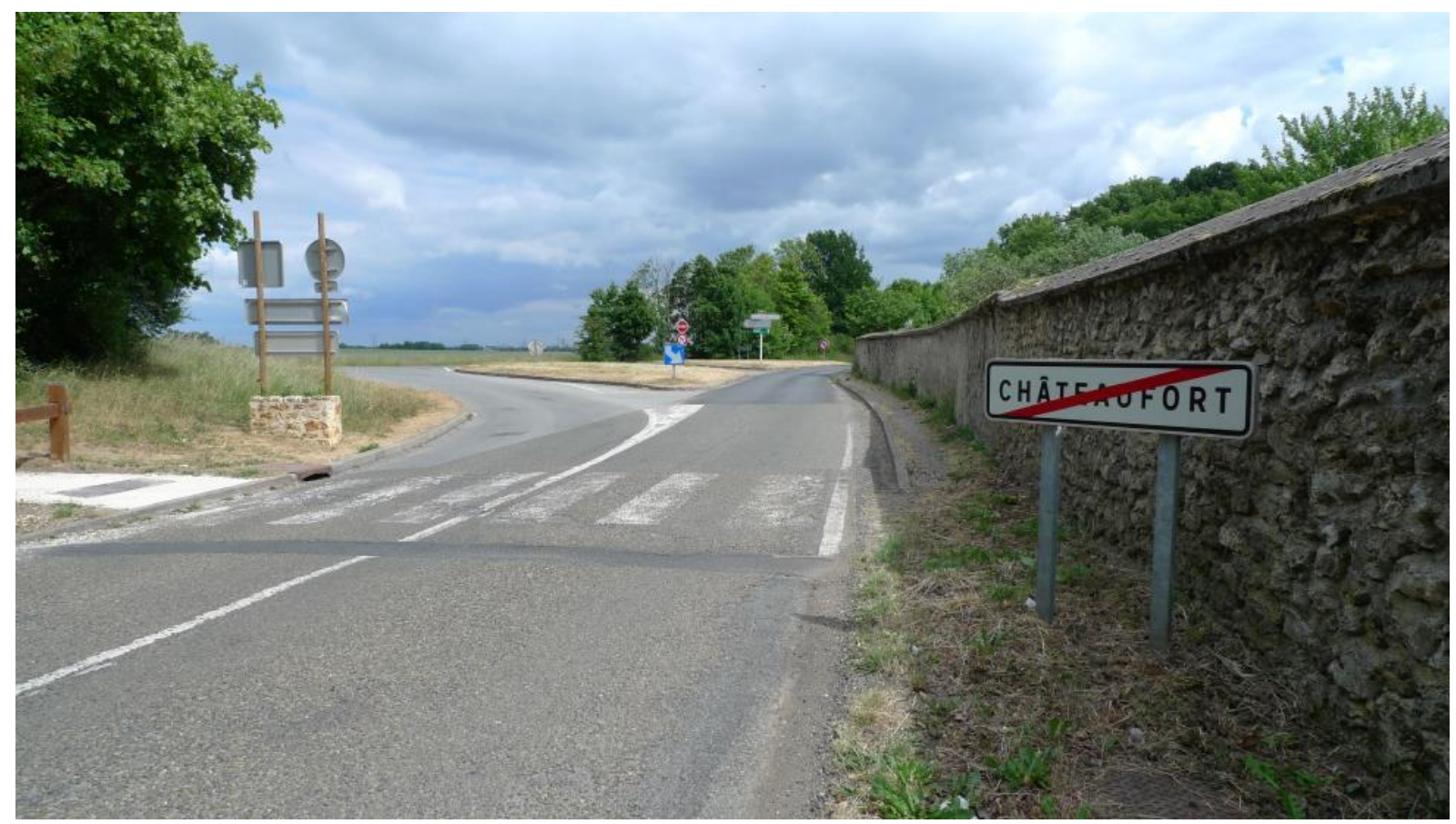


The fragmentation of the French municipal fabric gives residents' movements a singular ability to influence planning regulations. A metropolitan region like Lyon is composed of 514 municipalities with a population of 2.1 million, within which are about 380 periurban municipalities each with an average population of 1,560 inhabitants. In such municipalities, extremely local issues prevail in residents' concerns. At the same time, the prerogatives of those municipalities are far reaching, and include planning (which allows suburbanites to control types of construction, lot size, etc.). The resultant conservationist agenda acts as a significant barrier to redevelopment projects. This type of planning is often exclusive too, because it usually limits (or even halts) urbanization, which not only prevents population increase but also raises prices and thus restricts access to those who can afford to obtain entry (see Figure 10).

In Canada, suburban municipalities also play an important role, but they are much larger (see Table 2). And they (e.g. Surrey, BC; Mississauga, Ontario; Markham, Ontario; Laval, Quebec; Brossard, Quebec) challenge, rival and sometimes supersede the political centrality of the core city as they attempt to redefine their (sub)urban future in the context of more general calls for more sustainable (and now increasingly resilient) forms of development.

Figure 11: Industrial-residential mix: industrial plant in eastern Toronto suburb with encroaching highrise and single-family-home residential development (photo by Roger Keil)

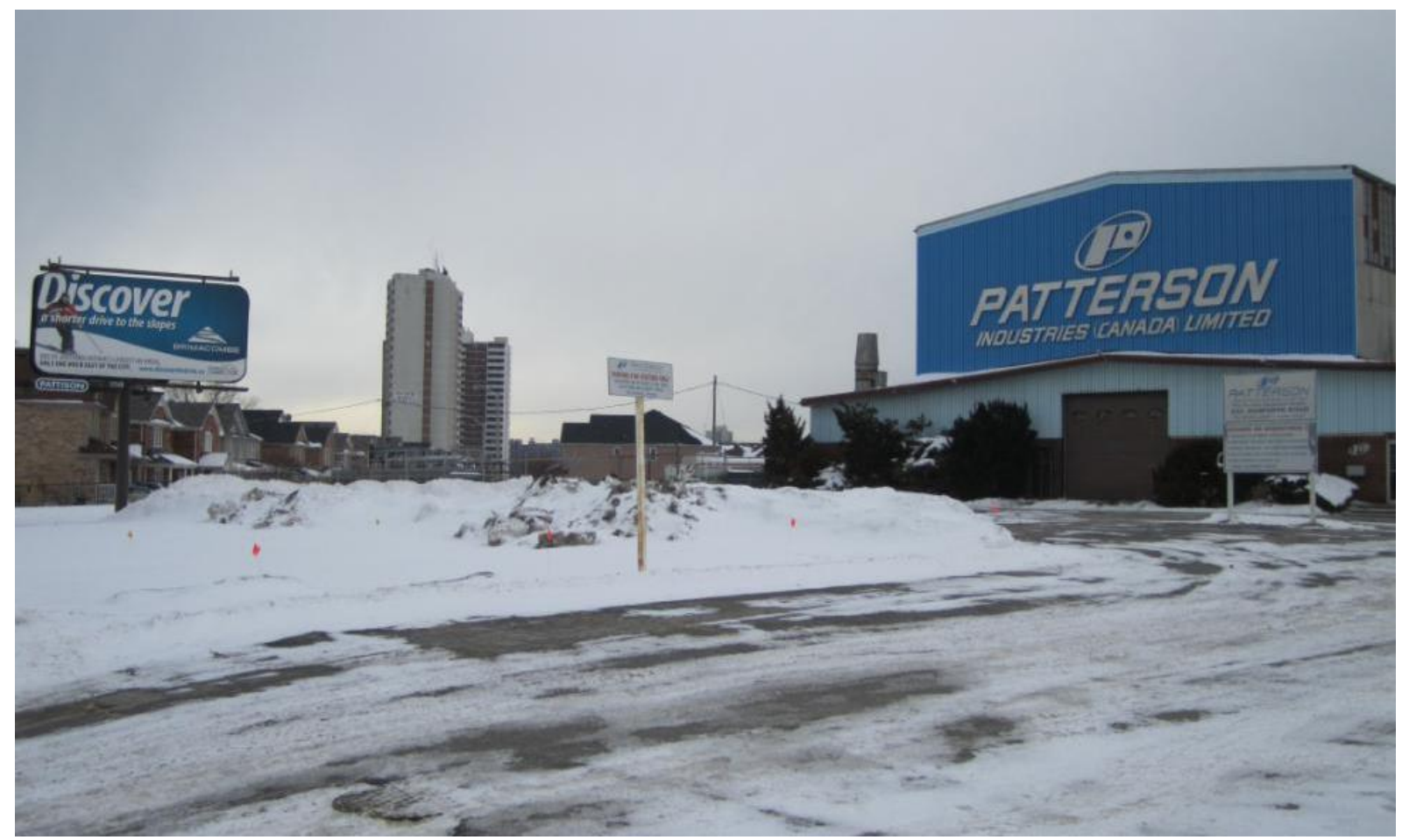

In any case, suburban politics is not only about residential qualities of places. The suburbs have historically often lacked employment. Gradually, however, the work commute has been reconfigured: the suburbs to centre transportation flow has lessened as more people commute from suburb to suburb, or even from centre to suburb, following employment opportunities in Fordist factories and post-Fordist manufacturing, logistics and office locations, as well as commercial and entertainment enterprises (see Figures 7, 11 and 12). In parallel, during the decades following the second world war, governments sought to organize suburban growth by creating new settlements and satellite cities. 
While this policy has had relatively limited impact in the US, the creation of the Municipality of Metropolitan Toronto in the 1950s was specifically linked to the siting of multi-density housing developments away from the centre (Young, 2006). In France, an ambitious policy of new town construction was launched in the late 1960s, and the five new towns created around Paris at that time now constitute major sub-centres (see Figure 10). Likewise, edge cities have developed around highway interchanges serving shopping malls in the US and Canada (Garreau, 1991). Large cities also include neighbouring smaller cities within their orbit, with all their shops, jobs, equipments and services. Finally, apart from edge cities, one notices a dissemination of employment and commerce to the outskirts, to what have been named 'edgeless cities' (Lang, 2003).

Within that context, in both France and Canada (albeit in different guises) suburban regimes that have historically been formed in contradistinction to the central city have recently been freeing themselves from the inside-outside duality traditionally characterizing their political frame. The increasing recognition of regional and 'in-between' issues, particularly in policy sectors such as transportation, welfare, ecology and housing, has led to an increase of rhetoric (if not action) regarding cooperation between suburbs and the central city on one hand, and coordination in a competitive regional environment among suburban municipalities in decentralizing regions on the other (Lehrer et al., 2012). These logics articulate themselves in variable configurations depending on context. In France, for example, while inner- and middle-ring suburbs clearly have an urban identity, and are often integrated into metropolitan communities (communautés urbaines) in which the core municipality cooperates with its neighbouring municipalities, periurban areas retain a more rural identity and tend to adopt a defensive stance against the city.

Figure 12: The Carré Sénart, south of Paris, in Île-de-France: this 'shopping parc' was designed by the planners of Sénart new town to be the centre of the whole development (photo by Eric Charmes)

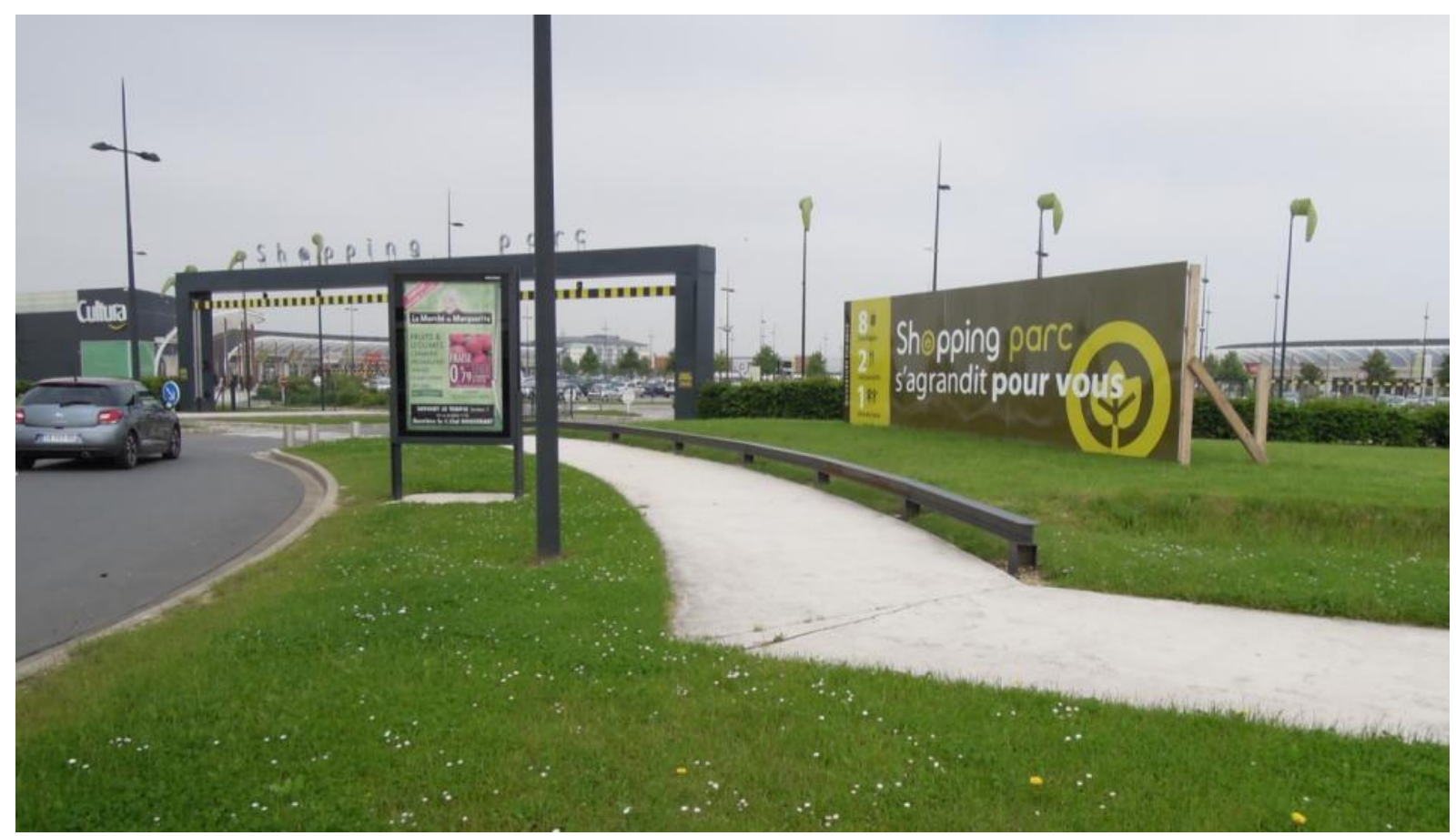


Again, space constraints prevent us from exploring in detail all the regimes presented in Tables 1 and 2. But the examples above, and the cases discussed in the essays, show the importance of considering densification and, more broadly, morphological transformations of suburbs in their respective contexts-considering different scales that interact. Suburbs are also extremely diverse, to a degree that makes it difficult to talk about suburbs or post-suburbs in general. From that perspective, the comparison between cities and between countries is very helpful. It helps to disentangle the contingent from the structural. It also helps to identify the various factors determining a suburban regime.

\section{The politics of post-suburban densification}

There are differences, but also similarities, in the formulaic morphology of post-second world war metropolitan landscapes, and in the crisis besetting those landscapes. The archetypes of the concrete residential tower and the single family pavillon are just the external markers of that dialectics of difference and convergence. Beyond that dialectics, in the debate we present here, we can note certain convergences. Both French and Canadian metropolitan suburbs and periurban areas are caught up in the frantic pace of modernization, although collective actors in both settings continue to mobilize around conservation of present scales, forms and communities. On both sides of the Atlantic, we detect strong conflicts between local and metropolitan perspectives, private and public interests, community and corporate actors. And we have noted the multifaceted nature of the suburban theatre of collective action, which cannot be dismissed as mere nimbyism.

The suburban political realm is not static, nor is it dormant. There are strong and growing mobilizations around issues of everyday suburbanism, but also around long-term planning and policy in regional matters. There are expectations in both Canada and France that there will be (decisive) state action when needed. While Canadian jurisdiction lies mostly with provincial government (of which local communities are mere creatures), in France the post-1981 decentralization has led to a strong dialectic of central and local political action.

These essays speak of multiple rationalized projects (the social, the environmental, the economic), around which actors play a political game in which they are conscious and deliberate participants that don't just react, but also set new boundaries and rules. In this sense, all the essays pay tribute to Logan and Molotch's (2007 [1987]) initial formulation, that sees suburbanization as a process of complex interrelationships of individual decisions in firm structures, located in a political universe of use and

exchange value decisions by individual and institutional actors. They speak of multiple scales and recognize the metropolitan significance of change in place (most notably in the case of Rousseau, this issue) and take seriously the actors that are involved. Suburbs are not just treated as objects of external planning and policy, but also as places subject to endogenous, maybe even autonomous, agency. All the essays presented here discuss different suburban forms (tower blocks, houses, pavillons, grands ensembles) and demonstrate an ability to discern the differences between those morphologies, the consequences they have for the political process and their engagement with the modalities of suburban governance. And finally, they all elaborate upon both the ideological and material aspects of the relationships of urban form and social structures, an important part of the new debate on suburbs and suburbanization to which we hope to contribute with this debate. The French essays (more than the Canadian essays) display a comparative perspective that involves an excellent recognition of the current state of debate on post-suburban politics. North American-European differences are critically acknowledged and productive solutions are found. The Canadian essays present two very different 
views of the changeability of suburban form (tower renewal versus stasis of the suburban morphology). They also engage different scales of suburbanization, one local and place-based, the other regional and trans-jurisdictional. The concepts we suggest readers of this debate might contemplate may be summarized in the terms 'soft' and 'hard', which are most forcefully introduced by Anastasia Touati who discusses densification in rather different suburban environments. Poppe and Young demonstrate that Toronto's peripheral concrete tower neighbourhoods, in respect of which reformers seek renewal, operate on the plane of both the hard material retrofit and the soft social engineering of inventing a new contextual fit for communities in a changing post-suburban landscape. Rousseau discusses the hard and soft edges of the urban region depending on alternative socioeconomic and political structures. And finally Filion's essay questions whether the suburban morphologies of Canadian urban regions are hard or soft, and likely to resist pressure for change.

We can conclude that post-suburbia has well and truly arrived, and we may propose that we need to accept that post-suburbia is now ubiquitous. No new frontiers are part of this particular set of case studies; their view is directed towards the inside. In all of this, there is some clear transatlantic convergence but also lots of diversity, both internally and between the French and Canadian cases. The debate also highlights the fact that comparative studies of this nature are now more important than ever in order to create productive conversations about what needs to be done. The choice of Canada and France for such a comparison was productive as it allowed the authors of the individual essays (as well as us as editors and editorializers of the case studies) to nod politely to the 'classical' US case, but then to break free of it, liberating innovative and new modes of thinking that engage with the shared realities and divergent idiosyncrasies of both cases.

The cases and the comparison leave us with the insight that all measures are inevitably socio-ecological and socio-economic, as well as politically negotiated. Despite clear path dependencies (in morphology, institutions, ideology and political process), political choices and options remain available in our postsuburban futures.

\section{References}

Addie, J.P., R. Fiedler, R. Keil (forthcoming) Cities on the edge : Emerging suburban constellations in Canada, In P. Filion, T. Vinodrai, R. Walker and M. Moos (eds.) Canadian Cities in Transition, $5^{\text {th }}$ edtn, Toronto, Oxford University Press.

Bacqué, M-H., Y. Sintomer (eds) (2004), Gestion de proximité et démocratie participative, une approche comparative, Paris, La découverte

Baudin, G., P. Genestier (2006), Faut-il vraiment démolir les grands ensembles ?, Espaces et Sociétés 124-125, 207-222

Béal V., M. Gauthier, G. Pinson (2011) Le développement durable changera-t-il la ville ? Le regard des sciences sociales, Saint-Etienne, Presses de l'Université de Saint-Etienne

Buchanan C. (1963) Traffic in Towns, London, Penguin Books

Bruegmann R. (2006) Sprawl: A Compact History, Chicago, University of Chicago Press.

Charmes, E. (2009) On the Clubbisation of the French periurban municipalities, Urban Studies 46.1, $189-212$

Charmes, E. (ed.) (2010a) La densification en débat, Etudes foncières 145, 20-38

Charmes, E. (2010b) Cul-de-sacs, superblocks, and environmental areas as supports of residential territorialisation, Journal of Urban Design 15; 3, 357-374

Charmes, E. (2011) La ville émiettée. Essai sur la clubbisation de la vie urbaine, Paris, Presses universitaires de France. 
Charmes, E. (2013) L'artificialisation est-elle vraiment un problème quantitatif ?, Etudes foncières 162, 23-28

Dikec, M. (2007) Badlands of the republic. Space, politics and urban policy, Cambridge, Blackwell

Echenique, M.H., A.J. Heargraves, G. Mitchell, A. Namdeo (2012) Growing cities systainably, Journal of American Planning Association 78.2, 121-137

Ekers, M., P. Hamel, R. Keil (2012) Governing Suburbia: Modalities and Mechanisms of Suburban Governance, Regional Studies 46.3, 405-422

Fishman, R. (1987) Bourgeois Utopias: The Rise and Fall of Suburbia, New York, Basic Books.

Garreau, J. (1991) Edge City: Life on the New Frontier, New York, Doubleday

Hamel, P., R. Keil (eds.) (2014) Suburban Governance: A Global View, Toronto, University of Toronto Press

Harris, R. (2010) Meaningful types in a world of suburbs. Suburbanization in Global Society Research in Urban Sociology 10, 15-47

Harris, R. (2004) Creeping Conformity How Canada became Suburban, 1900-1960. Toronto, University of Toronto Press

Harris, R. (1996) Unplanned Suburbs. Toronto's American Tragedy, 1900-1950, Baltimore, Johns Hopkins University Press

Holden, E., I. Norland (2005) Three Challenges for the Compact City as a Sustainable Urban Form: Household Consumption of Energy and Transport in Eight Residential Areas in the Greater Oslo Region, Urban Studies 42.12, 2145-2166

Hulchanski, D. (2010) The Three Cities Within Toronto. Income Polarization Among Toronto's Neighbourhoods, 1970-2005, Toronto, University of Toronto

Jaglin, S. (2010) Introduction : "Étalement urbain, faibles densités et 'coûts' de développement" Flux, 79-80, 6-15

Keil, R. (1994) Editorial, Global sprawl: "Urban form after Fordism?," Environment and Planning D: Society and Space 12.2, 131-136.

Keil, R., K. Ronneberger (1994) Going up the country: Internationalization and urbanization on Frankfurt's northern fringe, Environment and Planning D: Society and Space 12.2, 137-166.

Keil, R., M. Whitehead (2012) "Cities and the Politics of Sustainability" In K. Mossberger, S.E. Clarke, P. John (eds.) The Oxford Handbook of Urban Politics, Oxford University Press

Keil, R., D. Young (2011) "Post-Suburbia and City-region Politics", In N. Phelps, F. Wu (eds.) International Perspectives on Suburbanization: A Post-Suburban World? Houndmills, Basingstoke, Palgrave Macmillan, 54-77.

Keil, R., D. Young (2013) “In-Between Mobility in Toronto's New (Sub)urban Neighbourhoods" In P. Watt, P. Smets (eds.) Neighbourhood Belonging and Mobilities in the City and Suburb, Houndmills, Basingstoke, Palgrave Macmillan

Keil, R., P. Hamel, E. Chou, K.Williams (2014) Modalities of Suburban Governance in Canada, In P. Hamel, R. Keil (eds.). Suburban Governance: A Global View, Toronto, University of Toronto Press

Lang, R. (2003) Edgeless Cities: Exploring the Elusive Metropolis, Washington, D.C., Brookings Institution Press

Le Galès, P. (2002) European Cities: Social Conflicts and Governance, Oxford, Oxford University Press

Lehrer, U., R. Keil, B. Belina, S. Heeg (2012) "Producing global metropolitanism in the periphery: Toronto and Frankfurt," Paper presented at conference Governing the metropolis: Powers and Territories. New Directions for Research, Paris, November 28-30.

Logan, J., H. Molotch (2007, [1987]) Urban Fortunes: The Political Economy of Place, Berkeley and Los Angeles, University of California Press 
Mangin, D. (2004) La Ville franchisée. Formes et structures de la ville contemporaine, Paris, Editions de la Villette

Nessi, H. (2012) Influence du contexte urbain et du rapport au cadre de vie sur la mobilité en lle-deFrance et à Rome, Unpublished dissertation, under the direction of O. Coutard, Marne-laVallée University

Phelps, N.A., A.M. Wood (2011) The New Post-suburban Politics?, Urban Studies 48.12, 2591-2610

Phelps, N.A., F. Wu (eds.) (2011a) International Perspectives on Suburbanization : A Post-Suburban World ? Houndmills, Basingstoke, Palgrave Macmillan

Phelps, N.A., F. Wu (2011b) Introduction: International Perspectives on Suburbanization: A Postsuburban World? In: International Perspectives on Suburbanization: A Post-Suburban World ? Houndmills, Basingstoke, Palgrave Macmillan, 1-11.

Sewell, J. (2009) The Shape of the Suburbs: Understanding Toronto's Sprawl, Toronto, University of Toronto PressSieverts, T. (2003) Cities Without Cities. An Interpretation of the Zwischenstadt, London, Routledge

Subra, P. (2007) Géopolitique de l'aménagement du territoire, Paris, Armand Colin

Tissot, S. (2008) "French suburbs" : A New Problem or a New Approach to Social Exclusion ?, Harvard University, Center for European Studies Working Paper Series, 160Touati, A. (2010) « Histoire des discours politiques sur la densité » In E. Charmes (Ed.) "La densification en débat ", Etudes foncières, 145, 24-26.

Touati, A. (2013) Economie Politique de la densification des espaces à dominante pavillonnaire: l'avènement de stratégies post-suburbaines différenciées, Unpublished PhD Thesis, under the direction of Coutard, O. and Rutherford, J., Paris-Est University, Ecole Nationale des Ponts et Chaussées.

Walks, R.A. (2008) Urban Form, Everyday Life, and Ideology: Support for Privatization in Three Toronto Neighbourhoods. Environment and Planning A, 40.2, 258-282

Walks, R.A. (2007) The Boundaries of Suburban Discontent? Urban Definitions and Neighbourhood Political Effects. Canadian Geographer, 51.2, 160-185

Walks, R.A. (2006) The Causes of City-Suburban Political Polarization? A Canadian Case Study. Annals of the Association of American Geographers, 96.2, 390-414

Wolsink, M. (2006) Invalid theory impedes our understanding: a critique on the persistence of the language of NIMBY, Transactions of the Institute of British Geographers 31.1, 85-91.

Young, D. (2006) Rebuilding the Modern City After Modernism in Toronto and Berlin, Unpublished Dissertation, York University, Toronto

Young, D., P. Burke Wood, R. Keil (eds.) (2011) In-Between Infrastructure: Urban Connectivity in an Age of Vulnerability, Kelowna, BC, Praxis(e) Press

Young, D., R. Keil (2014) Locating the Urban In-Between: Tracking the Urban Politics of Infrastructure in Toronto, International Journal of Urban and Regional Research, published online. 